\title{
A Critical Review of the Concept of Transgenic Plants: Insights into Pharmaceutical Biotechnology and Molecular Farming
}

\author{
Rambod Abiri1,2, Alireza Valdiani ${ }^{1 *}$, Mahmood \\ Maziah $^{1,3,4 *}$, Noor Azmi Shaharuddin ${ }^{1 *}$, Mahbod \\ Sahebi ${ }^{4}$, Zetty Norhana Balia Yusof ${ }^{1}$, Narges Atabaki ${ }^{5}$, \\ Daryush Talei ${ }^{6}$ \\ ${ }^{1}$ Department of Biochemistry, Faculty of Biotechnology and \\ Biomolecular Sciences, Universiti Putra Malaysia, 43400 \\ UPM Serdang, Selangor DE, Malaysia. \\ ${ }^{2}$ Young Researchers and Elite Club of IAU, Kermanshah, \\ Iran. \\ ${ }^{3}$ Institute of Bioscience, ${ }^{5}$ Institute of Tropical Agriculture, \\ Universiti Putra Malaysia, 43400 UPM Serdang, Selangor \\ $D E$, Malaysia. \\ 4Institute of Tropical Agriculture, Universiti Putra Malaysia, \\ 43400 UPM Serdang, Selangor DE, Malaysia \\ ${ }^{5}$ IAU of Tehran Science and Research Branch, Tehran, Iran \\ ${ }^{6}$ Medicinal Plant Research Center, Shahed University, \\ Tehran, 3319118651, Iran.
}

${ }^{*}$ Corresponding authors:

Alireza Valdiani alireza.valdiani@gmail.com

Mahmood Maziah maziahm@upm.edu.my

Noor Azmi Shaharuddin noorazmi@upm.edu.my

http://dx.doi.org/10.21775/cimb.018.021

\begin{abstract}
Using transgenic plants for the production of high-value recombinant proteins for industrial and clinical applications has become a promising alternative to using conventional bioproduction systems, such as bacteria, yeast, and cultured insect and animal cells. This novel system offers several advantages over conventional systems in terms of safety, scale, cost-effectiveness, and the ease of distribution and storage. Currently, plant systems are being utilised as recombinant bio-factories for the expression of various proteins, including potential vaccines and pharmaceuticals, through employing several adaptations of recombinant processes and utilizing the most suitable tools and strategies. The level of protein expression is a critical factor in plant molecular farming, and this level fluctuates according to the plant species and the organs involved. The production of recombinant native and engineered proteins is a complicated procedure that requires an interand multi-disciplinary effort involving a wide variety of scientific and technological disciplines, ranging from basic biotechnology, biochemistry, and cell biology to advanced production systems. This review considers important plant resources, affecting factors, and the recombinant-protein expression techniques relevant to the plant molecular farming process.
\end{abstract}

\section{Introduction}

Currently, critical challenges in soil and water resources, as well as climate change, have resulted in the human population outpacing the available agricultural products. Thus, scientists are attempting to find various ways to increase the quality and quantity of the food, pharmaceutical and the industrial products of plants within limited arable spaces (De La Fuente et al., 2013). Phenotypic selection was the first action taken by humans to establish plant breeding as a reliable classical approach to this problem. Indeed, the history of plant breeding can be traced to the dawn of civilization, 10,000 years ago, when early societies began to shift from being huntergatherers to being members of agrarian communities (Tilman et al., 2002).

Gregor Mendel reached the first milestone in modern plant breeding. The results of his plant-breeding investigations led to the discovery of genetic functions through focusing on DNA as the basis of trait heredity (Acquaah, 2009). Although, conventional plant breeding has been used to overcome the lack of sufficient food or feed (Lopes et al., 2012), the success of this method is largely dependent on the breeder's experience and on phenotypic selection; consequently, inaccurate predictions can be made and low-efficiency breeding can occur (Mewett et al., 2007). Moreover, other limiting factors, such as the method being time consuming, the difficulty in finding the most related parents of a new generation of plants, selecting the best crossing method according to the plant traits desired, the high number of back-crosses required and the difficulties in increasing the expression of the favoured traits are the main concerns in plant breeding (De La Fuente et al., 2013).

Genetic modification (GM) is a new method that researchers have been using to increase the yield of plant products by improving certain traits, including the responses of herbs to abiotic and biotic stresses (Tait, 1999; Ashraf et al., 2008). Background genetic transformation is the most significant application of GM; in this process various methods are utilized to introduce desirable traits into the host genome while concentrating on preserving the individual characteristics of the plant (Ziemienowicz, 2013). The most important plants that have been successfully subjected to gene transformation programs are industrial plants, cereal crops, legumes, root plants, vegetables, turf grasses, tropic plants, woody species, medicinal and ornamental plants, as well as fruit plants (Wang, 2006a; Wang, 2006b). These plants and their related species have been presented in Table 1 . In gene transformation processes, the gene(s) of interest of donor plants, bacteria or viruses are transferred to host 


\begin{tabular}{|c|c|c|c|c|c|}
\hline $\begin{array}{l}\text { Model } \\
\text { Plants }\end{array}$ & Plants & References & $\begin{array}{l}\text { Model } \\
\text { Plants }\end{array}$ & Plants & References \\
\hline \multirow[t]{4}{*}{$\begin{array}{l}\text { Root } \\
\text { plants }\end{array}$} & $\begin{array}{l}\text { Carrot (Daucus } \\
\text { carota) }\end{array}$ & $\begin{array}{l}\text { (Zhang and Huang, } \\
2010)\end{array}$ & $\begin{array}{l}\text { Ornamental } \\
\text { plants }\end{array}$ & Carnation (Dianthus caryophylus) & (Burana et al., 2014) \\
\hline & $\begin{array}{l}\text { Cassava (Manihot } \\
\text { esclenta) }\end{array}$ & (Xu et al., 2012) & & $\begin{array}{l}\text { Orchids (Cymbidium spp., } \\
\text { Oncidium, Phalaenopsis) }\end{array}$ & $\begin{array}{c}\text { (Shu-Hong et al., } \\
\text { 2015) }\end{array}$ \\
\hline & $\begin{array}{l}\text { Potato (Solanum } \\
\text { tuberosum) }\end{array}$ & $\begin{array}{l}\text { (Park and Cheong., } \\
\text { 2002) }\end{array}$ & & Rose (Rosa hybrida) & $\begin{array}{c}\text { (Condliffe et al., } \\
2003)\end{array}$ \\
\hline & $\begin{array}{c}\text { Sweet potato } \\
\text { (Ipomoea batatas) }\end{array}$ & (Goo et al., 2015) & & Petunia (Petunia hybrida) & $\begin{array}{c}\text { (Kamenarova et al., } \\
\text { 2005) }\end{array}$ \\
\hline \multirow[t]{3}{*}{$\begin{array}{c}\text { Turf } \\
\text { grasses }\end{array}$} & $\begin{array}{c}\text { Perennial ryegrass } \\
\text { (Lolium perenne) }\end{array}$ & (Fischer et al., 2012) & $\begin{array}{l}\text { Industrial } \\
\text { plants }\end{array}$ & Sunflower (Helianthus annuиs) & $\begin{array}{l}\text { (Sankararao and } \\
\text { Rohini., 1999) }\end{array}$ \\
\hline & $\begin{array}{l}\text { Bermudagrass } \\
\text { (Cynodon spp.) }\end{array}$ & (Fischer et al., 2012) & & Indian Mustard (Brassica juncea) & (Fischer et al., 2012) \\
\hline & $\begin{array}{c}\text { Switchgrass } \\
\text { (Panicum virgatum) }\end{array}$ & (Wang, 2006a) & & Canola (Brasicca napus) & (Wang, 2006a) \\
\hline \multirow[t]{5}{*}{$\begin{array}{l}\text { Tropic } \\
\text { plants }\end{array}$} & Banana (Musa spp.) & (Wang, 2006a) & & Cotton (Gossypium hirsutum) & (Ashraf et al., 2008) \\
\hline & $\begin{array}{l}\text { Pineapple (Ananas } \\
\text { comosus) }\end{array}$ & (Wang, 2006a) & $\begin{array}{c}\text { Legume } \\
\text { plants }\end{array}$ & Alfalfa (Medicago sativa) & (Wang, 2006a) \\
\hline & $\begin{array}{c}\text { Sugarcane } \\
\text { (Saccharum spp.) }\end{array}$ & (Ziemienowicz, 2013) & & Beans (Phaseolus spp.) & (Wang, 2006a) \\
\hline & $\begin{array}{l}\text { Citrus spp., coffee } \\
\text { (Coffea spp.) }\end{array}$ & (Ziemienowicz, 2013) & & Soybean (Glycine max) & (Ziemienowicz, 2013) \\
\hline & $\begin{array}{c}\text { Papaya (Carica } \\
\text { papaya) }\end{array}$ & (Ziemienowicz, 2013) & & Pigeonpea (Cajanus cajan) & (Ziemienowicz, 2013) \\
\hline \multirow[t]{4}{*}{$\begin{array}{l}\text { Woody } \\
\text { species }\end{array}$} & $\begin{array}{l}\text { Eucalyptus, } \text { Pine } \\
\text { (Pinus radiate) }\end{array}$ & (Ziemienowicz, 2013) & & Peanut (Arachis hypogaea) & (Wang, 2006a) \\
\hline & $\begin{array}{c}\text { Cork oak (Quercus } \\
\text { suber) }\end{array}$ & (Dunwell, 2009) & & Peas (Pisum sativum) & (Ziemienowicz, 2013) \\
\hline & $\begin{array}{l}\text { Poplar (Populus } \\
\text { spp.) }\end{array}$ & (Wang, 2006b) & & & \\
\hline & $\begin{array}{c}\text { Rubber tree (Hevea } \\
\text { brasiliensis) }\end{array}$ & (Wang, 2006b) & & Chickpea (Cicer arietinum) & (Ziemienowicz, 2013) \\
\hline \multirow[t]{2}{*}{$\begin{array}{l}\text { Medicinal } \\
\text { plants }\end{array}$} & $\begin{array}{l}\text { Ginseng (Panax } \\
\text { ginseng }\end{array}$ & (Wang et al., 2005) & Cereal crop & Rice (Oryza sativa) & (Dunwell, 2009) \\
\hline & $\begin{array}{l}\text { Hemp (Cannabis } \\
\text { sativa) }\end{array}$ & (Wang et al., 2005) & & Maize (Zea mays) & (Ziemienowicz, 2013) \\
\hline \multirow[t]{4}{*}{$\begin{array}{l}\text { Nuts and } \\
\text { fruits }\end{array}$} & $\begin{array}{c}\text { Blueberry } \\
\text { (Vaccinium } \\
\text { corymbosum) }\end{array}$ & (Dunwell, 2009) & & Rye (Secale cereal) & (Dunwell, 2009) \\
\hline & $\begin{array}{l}\text { Walnut (Juglans } \\
\text { spp.) } \\
\end{array}$ & (Fischer et al., 2012) & & Sorghum (Sorghum bicolor) & (Dunwell, 2009) \\
\hline & $\begin{array}{c}\text { Strawberry } \\
\text { (Fragaria } \mathrm{x} \\
\text { ananassa) }\end{array}$ & (Dunwell, 2009) & & Wheat (Triticum aestivum) & (Dunwell, 2009) \\
\hline & $\begin{array}{l}\text { Apple (Malus X } \\
\text { domestica) }\end{array}$ & (Ziemienowicz, 2013) & & Barley (Hordeum vulgare) & (Ziemienowicz, 2013) \\
\hline \multirow[t]{2}{*}{$\begin{array}{l}\text { Vegetable } \\
\text { plants }\end{array}$} & $\begin{array}{c}\text { Tomato } \\
\text { (Lycopersicum } \\
\text { esculentum) }\end{array}$ & (Wang, 2006a) & Model plants & $\begin{array}{c}\text { Arabidopsis (Arabidopsis } \\
\text { thaliana) }\end{array}$ & (Wang et al., 2005) \\
\hline & $\begin{array}{l}\text { Lettuce (Lectuca } \\
\text { sativa) }\end{array}$ & (Ziemienowicz, 2013) & & $\begin{array}{c}\text { Tobacco (Nicotiana tobaccum, } N . \\
\text { benthamiana) }\end{array}$ & (Fischer et al., 2012) \\
\hline
\end{tabular}

plants using various methods, such as Agrobacterium mediation, particle bombardment (biolistics), the microprojectile gun method, electroporation, a siliconcarbide fibre-based technique, polyethylene glycol (PEG)mediated protoplast fusion, and liposome-mediated gene transfer, allowing the investigation of their effects (Rivera et al., 2012).

To date, transgenic plants have been engineered for the following purposes: to increase their tolerance of abiotic and biotic stresses (Lau et al., 2014; Wang et al., 2005), to improve their nutrient uptake (Sahebi et al., 2014), to reduce the effects of harmful agrochemicals and increase crop yields (Ziemienowicz, 2013), to allow phosphorus absorption and reduce the use of fertilizer (Hirsch and Sussman, 1999), to enhance grain production and the growth rate under the condition of low-iron availability (Takahashi et al., 2001) and to increase the aluminium tolerance of papaya and tobacco (De la Fuente et al., 1997). Some of the most significant genes transformed in the four plants of tobacco, rice, potato and Arabidopsis 
have been listed in Figure 1. By introducing Bt (Bacillus thuringiensis) toxin genes into rice, tomato, maize, tobacco, potato, cotton and other crop species, their insect resistance has been significantly increased (Singh et al., 2010).

There is evidence showing that the first application of herbs for medicinal purposes occurred during the period when Neanderthals lived (approximately 130,000 years ago), whereas more reliable evidence indicated that plant products have been used for therapeutic purposes as early as when the major human civilizations began, when the Egyptians collected at least 700 different medicinal plants in approximately $1600 \mathrm{BC}$. Consistent with this trend, the Romans used willow bark (Salix alba L.) to treat fevers (Ahmad, 2014; Kleiner, 1995). The functions of the ingredients of medicinal plants have been recently identified, allowing their use as prescription drugs (Mewett et al., 2007). Modern biotechnology is expanding the application of herbs in medicine well beyond the usual borders. Because plants can be the sources of medicinal proteins, including a blood-component substitute (Magnuson et al., 1998), mammalian antibodies (Fischer et al., 1999), and vaccine subunits (Walmsley and Arntzen, 2000), plant molecular farming can play a constructive role in the development of suitable transgenic plants. Using this technology, scientists have succeeded in introducing genes into host plants that induced them to produce pharmaceuticals (Torrent et al., 2009). In contrast to those who focus on other aspects of transgenic plants, plant molecular farming (PMF) researchers do not focus on conventional products, such as food, feed or fibre applications, but on producing industrial and pharmaceutical products (Sourrouille et al., 2009; Torrent et al., 2009). The first plant-based pharmaceutical protein was produced by Barta et al., 1986 during their investigations of producing human growth hormone in tobacco (Nicotiana tabacum). Since then, several other plant species, such as banana and potato, have been tested for the production of medicinal proteins (Schillberg et al., 2003). Although the notion of producing human proteins and antibodies in plants was initially met with great scepticism, nevertheless, crops offer a unique combination of advantages as well as interesting features compared with those of the traditional production systems. Generally, during the last several decades, plants have been widely investigated as unconventional systems for the production of pharmaceutical proteins.

\section{Plant molecular farming compared with conventional bioproduction systems}

Conventional molecular farming began in 1920 with the extraction of insulin from animal tissues by Fredrick Banting, as described by Dynkevich et al., 2013, but the drawbacks of this approach most likely led to the establishment new molecular farming methods through considering novel sources. New methods arose according to the molecular sources (e.g., plant cells, transgenic plant cells, virus-infected plants, animal cells, transgenic animals

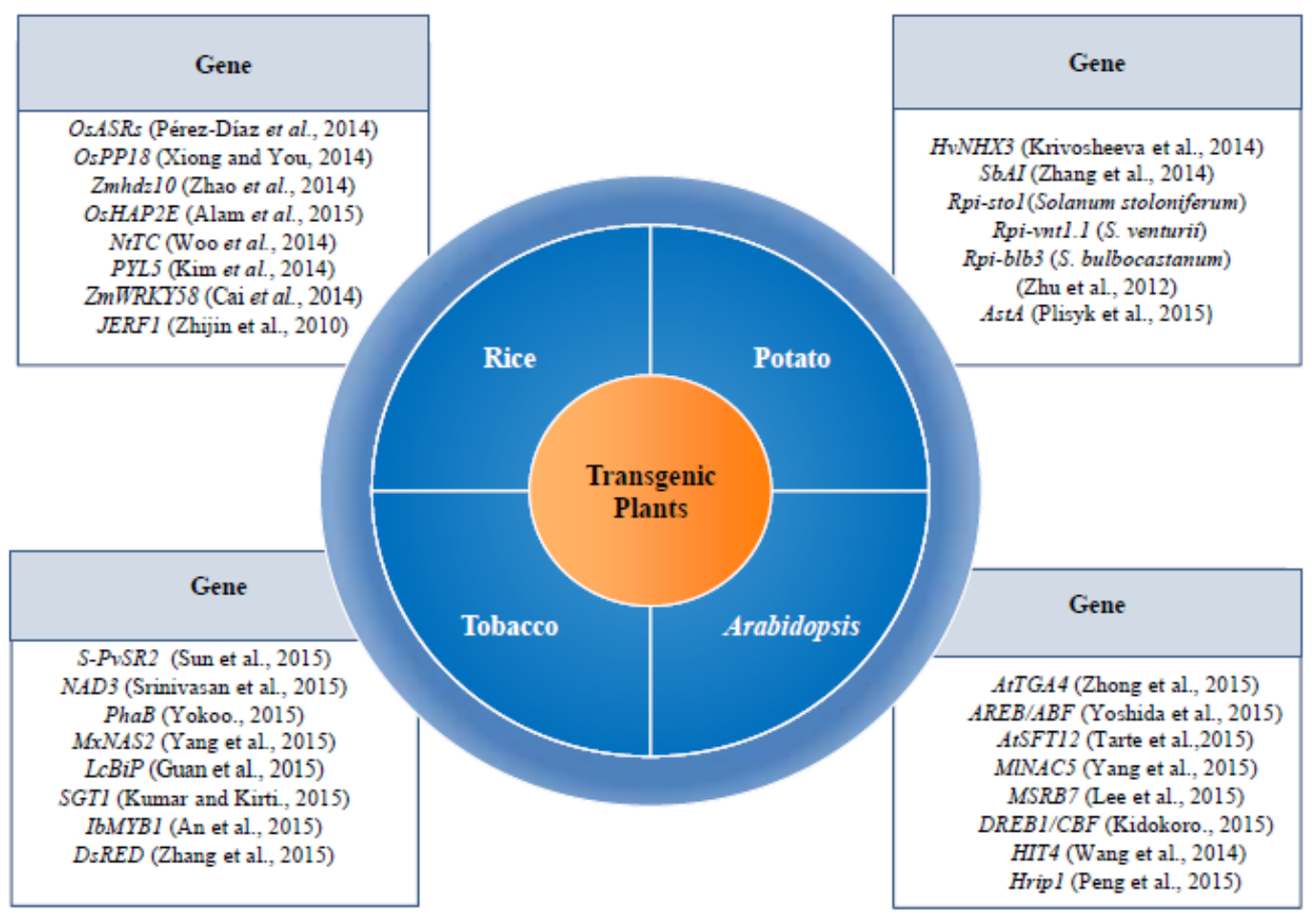

Figure 1. Groups various genes were transformed to model plants. 
and microbial cells). Accordingly, plant molecular farming is one of the outcomes of this process, and the major source in this field is the transgenic plant cell (da Cunha et al., 2014).

Compared with other transgenic products obtained from transgenic bacteria, fungi, and animals, which are the most common models for recombinant-protein production, plant-based therapeutics are produced with the lowest cost, leading to an economic justification for their use (Häkkinen et al., 2014). The availability of personnel with experience and expertise in planting, harvesting, and processing plant material are some of the other benefits of recombinant-protein production using molecular farming of higher plants. In addition, the dissimilarity of the pathogenic factors of plants and humans decreases the risk of microbial interactions that could negatively affect the quality of the final products. Technically, the stability of recombinant proteins within plants stressed by environmental factors is greater than that of recombinant proteins produced in other hosts. Furthermore, higher plants typically produce recombinant proteins with the correct folding, activity and glycosylation (Schillberg et al., 2005; Yano et al., 2010). Another beneficial characteristic of these systems is that recombinant plants can be stored at room temperature. In contrast, the storage temperature for plant viruses, bacteria and yeasts is $-20^{\circ} \mathrm{C}$. The storage condition for cultured mammalian cells is even more stringent because they must be maintained in liquid nitrogen (Faye et al., 2005). Among plant species, plants with watery tissues, such as tomato plants, are more suitable for molecular farming than are dry-tissue plants, such as cereals. This phenomenon could be related to the ease of extraction of squashy tissues (Horn et al., 2004). Despite all of the advantages of using higher plants, there are limits to the products than can be obtained using plant molecular farming, such as the unknown mechanisms that cause certain post-translational disorders in plant cells. The challenging issue of how to fine-tune the systems that are essential for the preservation of the structural integrity of the nascent recombinant proteins and their activities in their new cellular environments are still debated within the field of plant molecular farming (Walsh and Jefferis, 2006). The advantages and disadvantages of plant molecular farming compared with using other molecular farming systems are presented in Figure 2.

\section{Factors affecting the expression of recombinant proteins in different hosts}

According to the classification of final plant molecular farming products by Horn et al. (2004), proteins are clustered as parental pharmaceuticals, therapeutical intermediates, monoclonal antibodies (MAbs), industrial proteins, and antigens for use as edible vaccines (Figure 3). As green bioreactors, plants have various advantages, such as the capacity to accomplish eukaryotic posttranslational modifications that are necessary for biological activities, such as disulphide bridging and glycosylation, in many different mammalian proteins (Ma et al., 2003). The genetic transformation procedures employed are governed by various vital factors, such as the plant genotype, the

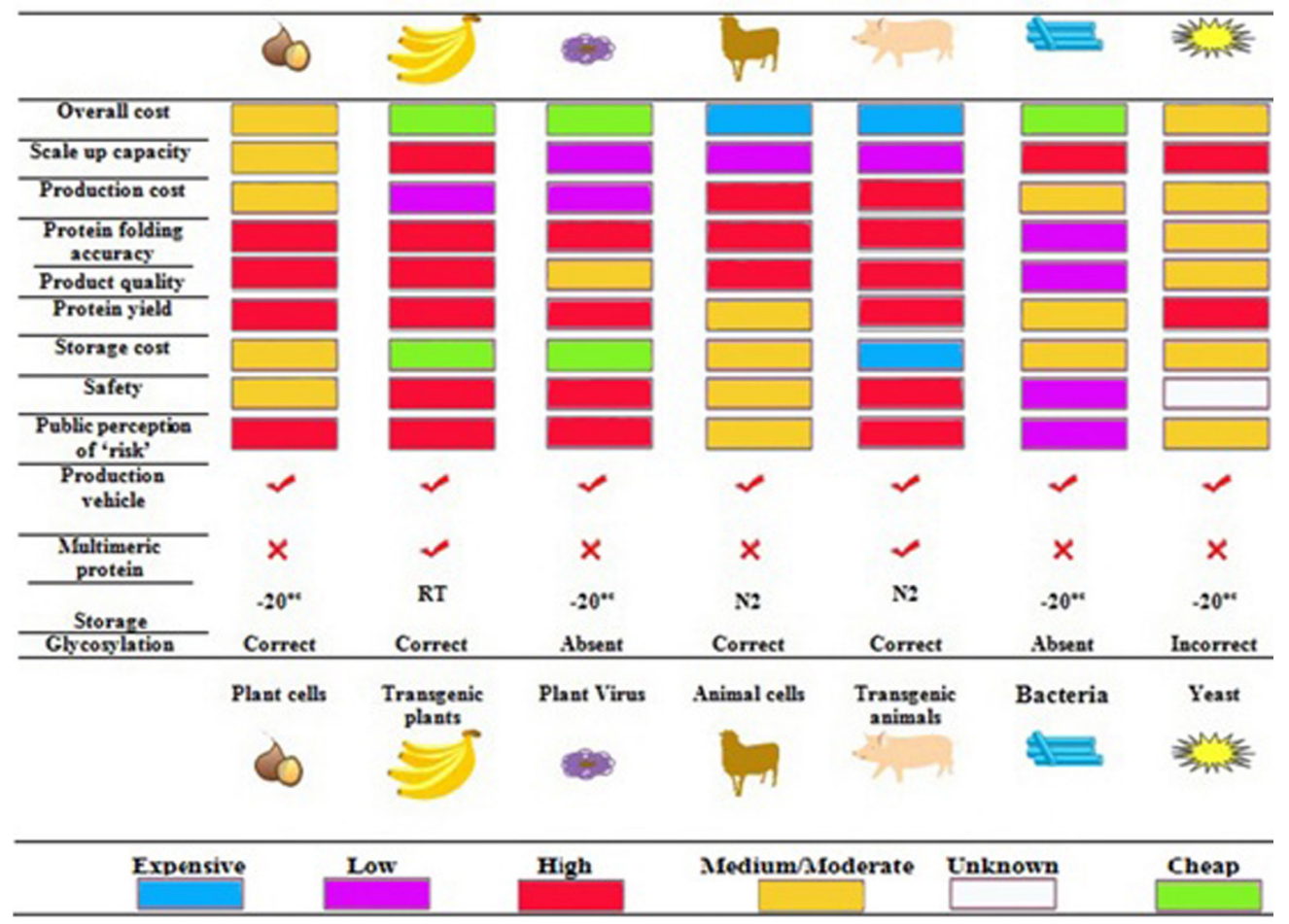

Figure 2. Comparison between various hosts in molecular farming. 
type of explant, the plasmid vector, the agrobacterial strain, and the composition of the culture medium (Kavitah et al., 2010; Sood et al., 2011). These factors play important roles in the transformation process that depends upon the plant species involved. Therefore, efficient plant molecular farming researchers tend to develop new transformation methods and novel construct designs, to incorporate welldefined transgenes and to search for more effective methods of introducing multiple genes into plants (Bregitzer and Brown, 2013; Karimi et al., 2013).

\section{Types of explants}

As mentioned above, the type of explant involved is one of the most vital factors for genetic transformation. For instance, the use of different sources of plant cells or tissues (e.g., seed, root, shoot, leaf, and shoot and root apical meristems) leads to variable results for callus induction, plant regeneration, and the efficacy of genetic transformation. In this regard, to produce a mass of calli, numerous protocols have been established for different plant-tissue culturing systems. Although these protocols are well-established, difficulties in callus induction in some plants, such as Indica rice varieties, are still experienced (Ikeuchi et al., 2013).

\section{Types of PGRs and plant regeneration}

The complicated procedure of plant tissue culture prompted the development of somatic embryogenesis (SE) methods, in which PGRs play an essential role. Two mainstream PGRs that have been used for plant tissue culturing are auxins and cytokinins. Members of the subgroups of each family are involved in different metabolic pathways that affect plant physiology. For examples, auxins cause the production of undifferentiated cells called callus cells. Apparently, PGRs induced methylation of DNA, whereas cytokinins affect root formation in tissue cultures. The auxins generally used for the induction of different callus tissues are 2,4-D (2,4-Dichlorophenoxyacetic acid), IAA (Indole-3-acetic acid), NAA (1-Naphthaleneacetic acid), Dicamba, Picloram and 2,4,5-T (2,4,5-trichlorophenoxyacetic acid) (Yokoya et al., 2014). In contrast, cytokinins are the best candidates for inducing the production of roots and of plant regeneration via calli. The main function of cytokinins appears to involve the synthesis of proteins necessary for the formation and functionality of the mitotic spindle apparatus (George et al., 2008). BAP (6Benzylaminopurine), Kinetin, Zeatin and TDZ (Thidiazuron) are the most important cytokinins that display regenerative activity in cultured plant tissues (Alam et al., 2010). Despite the undeniable effects of PGRs on cultured plant tissues, other essential factors, such as sugars, vitamins, salt concentrations, the type of medium and certain chemicals,

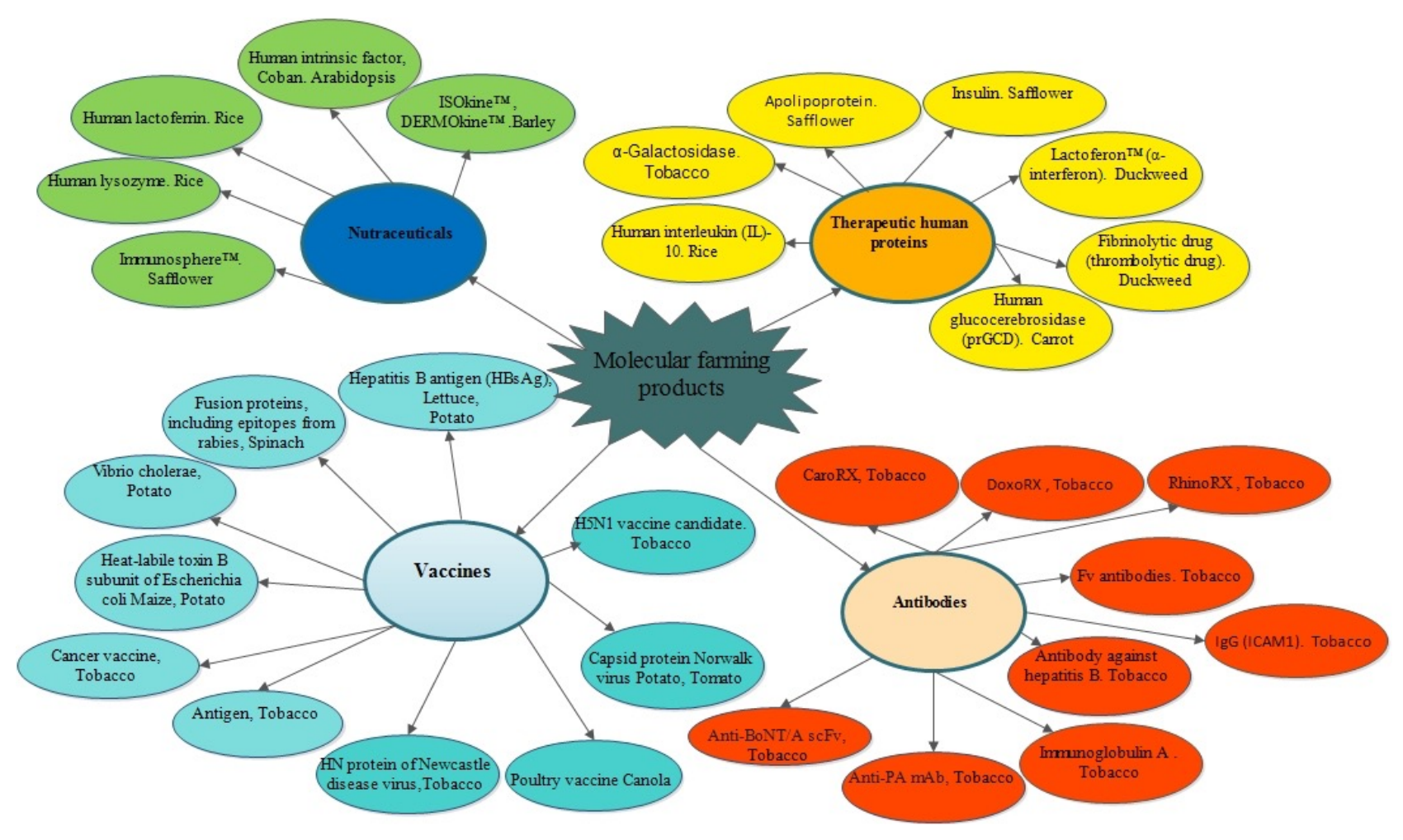

Figure 3. Examples of plant molecular farming products in different types of plants. 
have been found to be a key factors in somatic embryogenesis (Enríquez-Obregón et al., 1999; Kavitah et al., 2010; Murashige and Skoog, 1962).

Achieving the effective gene transformation systems in molecular farming largely depends on the efficiency of tissue culture methods. These methods are mainly affected by the plant source, such as calli, root and shoot. In several plants, the lack of effective regeneration system is the most important limiting factor preventing the successful gene transfer technologies.

\section{Plant vectors}

Scientists have many devices that allow them to achieve their goals of producing transgenic plants. In addition to various methods, such as the gene gun and biolistic techniques, natural bacterial vectors of plants, such as Agrobacterium tumefaciens, have been introduced as efficient tools, particularly in the case of cereals. Agrobacterium tumefaciens has the ability to transfer a portion of its DNA or so-called transferred DNA (T-DNA) to the genome of a host plant (Sheng and Citovsky, 1996). Agrobacterium-mediated gene transfer to plant cells includes five essential steps, as follows: a) induction of the bacterial virulence system, b) generation of a T-DNA complex, c) transfer of the T-DNA from Agrobacterium to the nucleus of the host cell, d) integration of the T-DNA into the plant genome, and e) the expression of T-DNA genes (Gelvin, 2012; Ziemienowicz et al., 2012). To date, Agrobacterium-based transformation methods have proven to useful approaches to genetically modify plants of various levels, including model plants such as the barrel clover (Medicago truncatula) Arabidopsis (Arabidopsis thaliana) and tobacco (Nicotiana tobaccum, N. benthamiana); cereals, such as maize (Zea mays), rye (Secale cereale), barley (Hordeum vulgare), wheat (Triticum aestivum), rice (Oryza sativa) and sorghum (Sorghum bicolor); legume plants, such as chickpea (Cicer arietinum); bean (Phaseolus spp.); pea (Pisum sativum); peanut (Arachis hypogaea), pigeon pea (Cajanus cajan); alfalfa (Medicago sativa); soybean (Glycine max); clover (Trifolium spp.); industrial plants, such as cotton (Gossypium hirsutum), canola (Brasicca napus), sunflower (Helianthus annuus), Indian mustard (Brassica juncea), Camelina sativa and Brassica oleracea; vegetable, such as tomato (Lycopersicum esculentum), eggplant (Solanum melongena), cucumber (Cucumis sativus), lettuce (Lectuca sativa), root plants; cassava (Manihot esclenta), carrot (Daucus carota), sweet potato (Ipomoea batatas) and potato (Solanum tuberosum); ornamental plants, such as carnation (Dianthus caryophylus), orchids (Cymbidium spp., Oncidium, Phalaenopsis), chrysanthemum (Dendranthema $\times$ glandiflora hybrid), rose (Rosa hybrida) and petunia (Petunia hybrida); tropical plants, such as Citrus spp., banana (Musa spp.), sugarcane (Saccharum spp.), coffee (Coffea spp.), pineapple (Ananas comosus), papaya (Carica papaya); grasses, such as turf grasses, perennial ryegrass (Lolium perenne), bentgrasses (Argostis spp.), bermudagrass (Cynodon spp.), tall fescue (Festuca arundinacea), switchgrass (Panicum virgatum); woody species, such as cork oak (Quercus suber), American elm (Ulmus americana), poplar (Populus spp.), eucalyptus, rubber tree (Hevea brasiliensis) and pine (Pinus radiate); nuts and fruits, such as apple (Malus $\times$ domestica), American chestnut (Castanea dentata), strawberry (Fragaria $\times$ ananassa), blueberry (Vaccinium corymbosum), walnut (Juglans spp.) and grapevine (Vitis vinifera); and final, medicinal plants, such as hemp (Cannabis sativa), ginseng (Panax ginseng) and the opium poppy (Papaver somniferum) (Dunwell, 2009; Ziemienowicz, 2013).

The major concerns that have arisen regarding transgenic plants include the low efficacy of plant regeneration during tissue culture, as well as production bottlenecks, such as in the spatial and temporal aspects of transgenic expression, target production, and the high-level yield of recombinant products (Stoger et al., 2002a; Streatfield, 2007). Considering that Agrobacterium is a pathogen of dicotyledonous species, the efficacy of the Agrobacterium-based genetic transformation of monocotyledonous plants is still limited due to the low integration rate. The above-mentioned difficulties prompted researchers to create new approaches to increase transformation efficiency. An Agrobacterium T-DNA derived nano-complex has been introduced as a promising method for increasing the transformation efficiency of monocotyledonous plants (Ziemienowicz et al., 2012). This nano-complex was first transferred into triticale (Triticum $\times$ Secale) microspores. The most important nano-complexes involve Agrobacterium T-DNA, virulence protein VirD2 and single stranded DNA- and double stranded DNA-binding RecA protein (Chugh et al., 2010).

\section{Promoters}

As the upstream elements of genes, promoters play an eminent role in gene expression. Promoters contain sites with core sequences to which RNA polymerase and transcription factors bind. Although constitutive promoters, such as the cauliflower mosaic virus 35S (CaMV35S) and the maize ubiquitin-1promoter, have been utilized in dicots and monocots, respectively, tissue-specific and inducible promoters provide better control of gene expression (Ko et al., 2005; Nguyen et al., 2004). Inducible promoters can be prompted to induce gene expression within selected spaces and at chosen times through the addition of the appropriate chemicals. Reportedly, applying these specific chemicals can inhibit the occurrence of the undesirable effects of gene expression on different stages of plant growth and development (Stöger et al., 2000). Another great advancement in the field of plant genetic transformation was the identification of tissue-specific promoters. These promoters control gene expression by restricting it to specific tissues, which decreases the extent of the diverse effects of transformation on the growth and development on the host plant (Stahl et al., 2002). However, the efficacy of gene expression in specific tissues depends on the availability of a promoter that induces the production of a sufficient level of protein (Ko et al., 2005; Ko et al., 2003). The level of gene expression obtained using a tissue-specific promoter is not always adequate for a molecular farming process designed to generate biotherapeutic proteins. This results could be due to the limited number of existing promoters, their activity during the regeneration process, and the unpredictability and complexity of the effect of environmental factors, all of 
which can cause unwanted and unexpected pleiotropic effects (Du et al., 2003). Indeed, expressing the series of genes necessary for the production of a full-size antibody requires the application of specific promoters that control the activity of each of these genes. In addition to the problems regarding plant protein expression mentioned above, the use of adverse promoters may cause homology-based gene silencing (De Neve et al., 1999; Ko et al., 2005). Applying both a constitutive promoter and an inducible promoter is a feasible solution to the aforementioned problems. For example, the combination of the $35 \mathrm{~S}$ promoter and the potato proteinase inhibitor II (pin2) promoter has been used to control the expression of the heavy- and light-chain antibody genes, respectively (Ko et al., 2003).

\section{Composition of RNA and DNA}

The process for the production of a recombinant protein in transgenic plants is similar to that of normal plants, in which DNA is transcribed to produce mRNA and then, through the harmonized activities of mRNA (messenger RNA), tRNA (transfer RNAs) and rRNA (ribosomal ribonucleic acid) mRNA is translated to yield a recombinant protein (Gebauer and Hentze, 2004). The untranslated regions of $\mathrm{mRNA}$ (the $5^{\prime}$ and $3^{\prime}$ untranslated regions) have direct effects on the transcriptional and translational processes via the activity of regulator- protein complexes (Amrolia et al., 1995; Costanzo and Fox, 1995). The core sequence of an untranslated region (UTR) of a gene may function as a gene-expression repressor when it binds translation-initiation factors. As a consequence of this activity, the translation of the gene product may be downregulated (Curie and McCormick, 1997). A motif within the $5^{\prime}$ UTR sequence of a gene can cause the specific induction of the transcription of its mRNA (Dickey et al., 1992). In parallel, the 5'-untranslated region of tobacco mosaic virus (Mitsuhara et al., 1996) and that of alfalfa mosaic virus (AMV) RNA3 have been shown to enhance the translation efficiency of a $\beta$-glucuronidase (GUS) transgene and stabilize its mRNA (Datla et al., 1993), which was also reported for the luciferase (Gallie and Kobayashi, 1994) and $\beta$-phaseolin (Oliver et al., 1993) genes. The cytoplasmic polyadenylation element (CPE) motif at the $3^{\prime}$ end of transcripts reportedly exhibited a regulatory function in mRNA translational events. In this regard, the above-described motif can stimulate protein translation by hastening the occurrence of polyadenylation (Kervestin and Amrani, 2004). Additionally, transgenic plants containing the untranslated leader sequence of AMV had higher levels of attacin and a recombinant lytic protein than did the plants that did not contain this sequence (Ko et al., 2000).

Thus, modifying the structural stability of mRNA and controlling RNA polyadenylation via $5^{\prime}$ and $3^{\prime}$ untranslated sequences of mRNAs, respectively, are useful translational-based approaches to increasing the production of recombinant proteins in transgenic plants. Differences in the codon usage of the transgene and the expression host will also affect the level of recombinantprotein expression. Codon optimization has been used to improve the level of recombinant-protein expression in living organisms by increasing the translational efficacy of the transgene (Mechold et al., 2005).

Additionally, extensive modification of the coding region and of certain molecular factors, such as accommodating codon bias, altering the GC content, eliminating cryptic splicing sites, putative polyadenylation signals and mRNA-instability sequences and incorporating $5^{\prime}$ and $3^{\prime}$ regulatory sequences, are required to achieve the high-level expression of foreign genes in plants (Streatfield and Howard, 2003).

Many candidate plant species for the production of recombinant proteins have been evaluated and developed during the past 25 years based on their particular advantages and disadvantages. These candidates from the plant Kingdom includes those that can be applied in cell cultures (carrot, tobacco, and rice), leafy crops (alfalfa, tobacco, and lettuce), aquatic plants (Lemna minor) and seed crops (canola, soybeans, corn, and rice) (Franconi et al., 2010; Karg and Kallio, 2009).

\section{Tobacco}

One of the most suitable platforms typically used as a green producer is tobacco (Nicotiana tabacum). Despite the application of tobacco in smoking, it has many unique advantages over other plant species for the production of pharmaceutically relevant proteins. Scientists believe that the role of tobacco in recombinant-protein investigations is similar to that of the white mouse in mammalian studies over the last 20 years. As a leafy species, tobacco has numerous advantages over other plants, which have encouraged researchers to focus on this plant as an undeniable alternative for recombinant protein expression. This herb is capable of producing a biomass of up to 100 ton/ha. Moreover, a well-established system for transforming tobacco that results in a high level of soluble protein exists. The potential of utilizing various strategies for the expression of proteins in a stable or transient manner using this species, as well the possibility of using chloroplast genome-based methods mediated via Agrobacterium or viral induction are its other advantages (Figure 2) (Karg and Kallio, 2009). Nevertheless, the high concentrations of alkaloids and nicotine in some tobacco varieties are disadvantageous to utilizing this plant for molecular farming. These drawbacks have been compensated for by breeding new cultivars such as "81V" (Ma et al., 2003). The instability of the products of tobacco is one of the disadvantages of this plant in molecular farming. Alternatively, its products can be immediately processed on farms; alternatively, the leaves can be dried or frozen before transport to processing plants (Kamenarova et al., 2005). Tobacco is not a feed or food crop, which decreases the probability of its contamination within the feed or food chains. In addition, tobacco can produce a wide variety of therapeutic immune-modulatory molecules, such as cytokines, vaccines and antibodies (Tremblay et al., 2010). A full-length monoclonal antibody (mAb) directed against a mouse catalytic IgG1(6D4) was the first antibody produced in tobacco plants (Hiatt and Pauly, 2006). Other antibodies that were generated using tobacco plants include anti-PA (protective antigen) $\mathrm{mAb}$, anti-BoNT/A scFv (botulinum neurotoxin/antibody singlechain variable fragment) idiotype specific antibodies, anti- 
Lewis $\mathrm{Y}$ mAb, H10 mAb, CO17-1A mAb, TheraCIM ${ }^{\circledR}, \mathrm{B} 294$ mAB, B303 mAb, 2F5 mAb, R12 mAb, CaroRX ${ }^{\mathrm{TM}}$, and antiLPS ScFv, as well as antibodies targeted against different disease entities, such as anthrax (Hull et al., 2005), botulism (Almquist et al., 2006), cancer (B-cell lymphoma) (Young et al., 2009), (breast and colon) (Brodzik et al., 2006), (broad spectrum) (Svanes et al., 2010), (colon) (Ko et al., 2005), (skin) (Rodriguez-Oroz et al., 2005), as well as hepatitis (Gleba et al., 2005), HIV (Human immunodeficiency virus) (Ward et al., 2007), rabies (Girard et al., 2006), S. mutans colonization (Ma et al., 1998), and Salmonella (Makvandi-Nejad et al., 2005). Vaccines are antigenic materials that are administered to produce immunity to diseases. To date, various types of these vaccines have been generated in tobacco and some of them have been tested in mammals. The cysteine protease Der p 1 (Dermatophagoides pteronyssinus allergen) (Johnston et al., 2009; Lienard et al., 2007), Der p 2 (Lienard et al., 2007), protective antigen (Koya et al., 2005), L1 major capsid protein (Lenzi et al., 2008), CTB (cholera toxin B) (Jani et al., 2004), multi-epitope vaccine (Soria-Guerra et al., 2009), VCA (viral capsid antigen) (Lee et al., 2006), VP1 (viral protein-1) (Wu et al., 2007), VP21 (Huang et al., 2009), HSP-A (heat shock protein) (Brodzik et al., 2006), UreB (urease subunit beta) (Gu and Glatz, 2007), HBsAg (Hepatitis B antigen) (Thanavala et al., 1995), Hep C (Hepatitis C) core protein (Nanou and Azzouz, 2009), HIV p24 capsid protein (Zhang et al., 2002), HIV-Nef (human immunodeficiency virus- Negative regulatory factor) (Marusic et al., 2007), F1-V, SARS-CoVS1protein (severe acute respiratory syndrome coronavirus) (Pogrebnyak et al., 2005), Tet-C (tetanus toxin Fragment C) (Tregoning et al., 2005), GAD65 (Mr 65,000 isoform of glutamic acid decarboxylase) (Ma et al., 2004), GAD67 (glutamic acid decarboxylase) (Ma et al., 1997), HSP-60 (Heat shock protein 60) (Tremblay et al., 2010), insulin (Lee et al., 2006) and GLP-1 (Glucagon-like peptide-1) (Brandsma et al., 2009) are some of the proteins that have been expressed in tobacco, which target diseases/disease entities such as allergy-dust mites, anthrax, cancer (cervical), cholera, DPT (diphtheria), Epstein-Barr virus, foot and mouth disease, Helicobacter pylori, hepatitis B/C, HIV, plague, SARS, tetanus, Type 1 diabetes and Type 2 diabetes, respectively.

Cytokines, some of which are glycoproteins, are members of a family of strong immunoregulators that are produced by different types of cells. The function of these small proteins is regulating the period and intensity of the immune response by inhibiting or stimulating the activation, proliferation, and differentiation of a variety of cells. This procedure is accomplished through regulating the secretion of Abs or other cytokines by target cells (Parkin and Cohen, 2001). Cytokines bind to cytokine receptors expressed on the membrane of the responsive target cells (Thomson and Lotze, 2003). Despite the availability of various commercial recombinant cytokinins, considering the limitations of some conventional bioproduction systems, such as low levels of expression and the lack of glycosylation of $E$. coli-derived recombinant cytokines, scientists are interested in producing such recombinant proteins using tobacco. Due to the low efficiency of $E$. coli production of a pleiotropic regulatory cytokine, such as human IL-13, which protects against several human diseases, including Type-1 diabetes mellitus (T1DM), transgenic tobacco can be used as a reliable system for the generation of high levels of human IL-13 (Thompson and Debinski, 1999; Wang et al., 2008). Transplastomic plants are novel alternatives to nuclear transgenic plants, which are created by introducing the recombinant DNA into the genome of chloroplasts rather than the nuclear genome using gene-gun bombardment. Some of the most important accessible products that have been produced in tobacco chloroplasts are a tetanus-toxin fragment, serum albumin, and human growth hormone. However, plastids do not have the capacity to perform glycosylation; thus, chloroplast cannot be used to produce human glycoproteins (Ma et al., 2003).

\section{The expression of tobacco systems}

The availability of various tobacco expression systems with their particular strengths is another advantage of this model plant over other plant species. Nuclear transformation is the appropriate method to achieve the long-term production of glycoproteins, such as antibodies. Alternatively, chloroplast-based expression systems allow the production of large amounts of proteins that require certain types of post-translational processing. Tobacco is amenable to several different simultaneous applications and has the potential to excel at each of them. When a product that requires rapid modification, as in the case of the abovementioned idiotypic anti-cancer vaccine, transient expression can be anticipated to yield the proper quantities of the desired protein within a short period (Tremblay et al., 2010). Using transient protein-expression systems, researchers can produce considerable amounts of recombinant protein during a short period, which is crucial for the rapid response to a disease outbreak, as is the case when a new influenza appears, e.g., during the $\mathrm{A} / \mathrm{H} 1 \mathrm{~N} 1$ pandemic, as well as for patient-specific cancer treatments.

\section{Nuclear transformation}

Stable nuclear transformation involves the incorporation of an exogenous gene into the nuclear genome of a plant, which leads to the expression of the new heritable traits by the next generation of transgenic plants. This transformation method is commonly utilized for the production and accumulation of a recombinant protein in certain explants, such as the dry seeds of cereals (Horn et al., 2004).

Agrobacterial infection and biolistic delivery are the two mainstream methods used to transform an exogenous gene into the nuclear genome of plants, including tobacco. Agrobacterium transfers genes to dicots with great efficacy and the Agrobacterial-infection method has been improved to increase the efficacy of the genetic transformation of certain monocotyledonous plants. The best example of the success of the latter involves rice (Chan et al., 1993; Chen, 2008; Hiei et al., 1997).

Furthermore, decreased costs and simplification of the production process are the results of gene delivery leading to stable genetic integration, which frequently leads to the production of recombinant proteins with the least external input. The exogenous proteins produced due to nuclear transformation can be directed to various secretory 
organelles or other organelles for standard eukaryotic posttranslational modifications.

Although nuclear transformation systems are commonly employed, the low level of production of the resultant recombinant protein remains a matter of concern. Among the many strategies to address this issue, the most important are the use of $5^{\prime}$ enhancer sequences to increase translational productivity, the use of promoters with strong tissue-specific constitutive activity, the use of a sub-cellular localization signal (Benchabane et al., 2008), the use of $3^{\prime}$ untranslated regions that were modified to increase transcript stability and the optimization of the coding sequence of the transgene using the typical tobacco codons (Streatfield, 2007; Streatfield and Howard, 2003), the addition of fusion partners that increase protein stability/proteolysis resistance (Floss et al., 2007), and targeting proteins to the endoplasmic reticulum (ER) via the attachment of a C-terminal $(\mathrm{K} / \mathrm{H}) \mathrm{DEL}$ signal (Denecke et al., 1992). The most important factors that directly affect the performance of stable transformation are the variety and the physiology of the plant.

\section{Transient transformation}

Transient transformation is the proper method to achieve the rapid production of vital proteins in tobacco. In contrast to the case of stable genomic integration, a large amount of recombinant protein can be produced in less than five days post-infection using the transient transformation method. Nevertheless, nuclear and transient transformation methods have similar advantages. For the production of pharmaceutical materials using viral coding sequences via Agrobacterium tumefaciens, transient expression is the proper method because it offers a high level of expression with the lowest input. Different strategies have been developed to increase the efficiency of transient expression. One of the successes achieved by scientists as a promising approach to directly transforming cells with a virus using Agrobacterium tumefaciens has decreased the energy required for genetically transforming tobacco (Gleba et al., 2005). The principle of this method to transfer specific components of the viral expression platform by mixing a dissimilar Agrobacterium strain harbouring portions of the viral machinery, with recombination occurring intracellularly once infection has occurred. By manipulating the viral codons and applying classic eukaryotic introns, the efficiency of gene delivery has been significantly increased. Thus, the required amount of the essential infectious Agrobacterium was reduced. For example, 1 litre of an overnight culture could be used to infect nearly $1000 \mathrm{~kg}$ of tobacco leaf tissue, yielding up to 4 $\mathrm{kg}$ of recombinant protein at $40 \%$ TSP (Marillonnet et al., 2005). This example demonstrates represents the scale that are presently being explored to maximize protein yield while reducing the input costs, resulting in an estimated $\$ 1 /$ $\mathrm{kg}$ of raw protein or $\$ 50 / \mathrm{kg}$ of purified protein. Another alternative is to insert the viral machinery required to prevent tobacco-gene silencing via stable nuclear transformation. Applying this method will decrease the delivery requirements of the deconstructed viral vectors (Azhakanandam et al., 2007). In general, transient expression has two main problems, including the high technical requirements for induction and high risk of accidentally spreading the infection to wild species. In addition, this method is limited to controlled conditions, such as those of a greenhouse or laboratory. Although, the latter drawback is less of a concern because the controlled environments eliminate the risks of cross-fertilization that could potentially occur when transgenic plants are grown in open fields. The agro-infiltration method that was developed by (Dillen et al., 1997) is another technique for transient expression. This method involves the infiltration of a suspension of recombinant Agrobacterium tumefaciens into tobacco leaf tissue, which in turn facilitates the transfer of T-DNA to a very high percentage of the cells. The method also positively affects the intensity of transient expression in transgenic crops. A method allowing transient expression in tobacco has been specifically developed as a very rapid and high-yield strategy for the production of clinical-grade bio-pharmaceuticals (Pogue et al., 2010; Vézina et al., 2009).

\section{Plastid transformation}

Plastid transformation is an efficient alternative to nuclear transformation because has several advantages that latter method lacks. For example, despite the enormous importance of the delivery of a normal bio-containment of transgene flow by out-crossing, the transgene cannot be transferred due to the lack of chloroplasts in pollen, thereby allaying public concerns regarding genetically modified plants (Meyer et al., 2010; Pantaleoni et al., 2014). Transgenic plants subjected to homoplastomic chloroplast transformation are selected after several generations of plants have been regenerated from the gene-gun bombarded leaf explants, meaning that the plant chloroplast genome has had opportunity to incorporate the transgene. The selection of the above-mentioned bombarded leaf explants is conducted on a medium containing a either spectinomycin or streptomycin. Researchers have achieved a noticeable yield of therapeutic human and bacterial proteins, ranging from $3-6 \%$ of the total soluble proteins, using the tobacco chloroplast-transformation technique (Reddy et al., 2002; Oey et al., 2009) achieved very high-level expression of a proteinaceous antibiotic, which comprised approximately $70 \%$ of the soluble proteins, through employing a chloroplast transformation system, which is the most significant yield of recombinant protein attained using transgenic plants to date. Although plastid transformation has an enormous potential, its application remains restricted. In that regard, even though plastid transformation has been attained in plant species, such as lettuce, eggplant, soybeans and tomatoes (Bock, 2007), the plant most commonly modified using a chloroplast transformation system is tobacco, which is highly regulated and is inedible due to its high level of toxic alkaloids. Finally, whether the protein stability will change over time, even with refrigeration, is a matter of concern (Horn et al., 2004).

\section{Plant-cell suspension cultures}

One of the best plant-based alternatives to mammalian cells for the production of biopharmaceuticals is a plant-cell suspension, which is a robust system involving a simple purification procedure and easy downstream processing 
(Kim et al., 2008). Although this system requires a high level of sterility to control contamination, pharmaceuticals with a high level of purity can be produced using it (Franconi et al., 2010). Additionally, in contrast to plant-cell culture systems, plant-cell suspension systems eliminate the regeneration process, and accordingly, is a rapid procedure (Shaaltiel et al., 2007). Despite having numerous advantages over other systems, plant-cell suspension systems have been established only for a small number of plants, such as tobacco, carrot, Arabidopsis and rice. Moreover, due to the certain limiting factors, such as increasing proteolytic activity, which leads to a low concentration of the recombinant protein during the late stationary phase, this system is not the best method of protein expression (Obembe et al., 2011).

\section{Arabidopsis}

Plants with appropriate traits have been discovered in genetic-engineering investigations. Of all the known plants in the Kingdom, Arabidopsis has been the main plant used for genetic transformation. Among the traits of Arabidopsis, the short generation period, small genome size, presence of a self-pollination mating system, ease of in vitro culturing, easy regeneration and in vivo transformation, as well as its lack of food and feed applications, are interesting characteristics that have led scientists to exploit this model plant (Koornneef and Meinke, 2010). Due to its prolific seed production and rapid propagation rate, Arabidopsis appears to be capable of generating a range of various products. Like other seed-producing plant bioreactors, for the production of recombinant proteins, Arabidopsis should be transformed during the early stages of growth, because its development toward the flowering stage may increase the risk of environmental contamination (Ruebelt et al., 2006). High levels of recombinant protein accumulation in Arabidopsis seeds have been achieved using a seed-specific expression cassette (Van Droogenbroeck et al., 2007).

\section{Cereals and legumes}

As protein synthesis and protein storage organelles, seeds have a critical role in plant molecular farming. The most important reasons for a seed-based system being an ideal platform for molecular farming are that seeds allow the long-term storage of proteins due to having an appropriate biochemical environment, a low water content and low protease activities and that they possess biosafety and are easy to transport (Stoger et al., 2002b). The lack of phenolic components is another advantage of cereal seeds compared to other plant bioreactors, such as tobacco, that contain phenolic components in their leaves. Generally, the downstream process of removing phenol from the products is time consuming and expensive (Ma et al., 2003). As is the case for other plant bioreactors used in molecular farming, seed-based systems have some drawbacks. The seed-based transgenic plants must reach the flowering stage before the recombinant proteins can be extracted, which significantly increases the possibility of environmental contamination by the pollen of the transgenic plants. To reduce the risk of this type of environmental contamination, plant bioreactors that accumulate recombinant proteins in their vegetative organelles are preferable to systems involving the flowering cycle (Twyman et al., 2003).

Cereals have particular characteristics that have encouraged scientists to use members of this family as model plants in molecular farming. Cereal endosperms are the most important components for researchers due to their soluble-protein content. Soluble proteins can be recognized and separated easily in cereals by displaying antibody role in molecular farming (Han et al., 2006). Among the cereals, wheat is not as an appropriate model plant because of the low efficiency of its transformation (Stevens et al., 2000). Some of the recombinant proteins that have been extracted from seed bioreactors are the most efficient vaccine antigens (Wu et al., 2007), cell-culture proteins (Nandi et al., 2002), industrial enzymes (Hood et al., 2007), therapeutic antibodies (Stöger et al., 2000) and cytokines (Zhu et al., 1994). Among the seed-based bioreactors, maize is the major viable plant that produces recombinant proteins in large amounts. Some of the remarkable features regarding this model plant compared with those of other plant systems used in molecular farming are the existence of well-established techniques for its tissue culture and transformation, its production of high levels of biomass and the ease of scaling up its use. Moreover, this plant has the ability to produce recombinant antibodies as well as protease inhibitors and enzymes for pharmaceutical/technical applications, such as aprotinin, laccase, and trypsin (Hood, 2002).

One of the initial plant molecular-farming investigations was conducted in 2003 by Xue, who used barley as a bioreactor to produce a highly active and thermo-tolerant hybrid cellulase (1,4-ß-glucanase) (Xue, 2003). Other types of recombinant proteins and materials have been produced in barley, of which serum albumin, lactoferrin, lysozyme, a1-antitrypsin and human antithrombin III are the most important examples (Stahl et al., 2002). Using rice as the host plant, Anzai and colleagues have successfully expressed human lactoferrin (Anzai et al., 2000). The recombinant single-chain $\mathrm{Fv}$ antibody directed against carcinoembryonic antigen that was produced in wheat and rice could be preserved for up to 4 or 5 months at room temperature without any loss in activity or of the product (Stöger et al., 2000). Although soybean and alfalfa plants produce a relatively smaller amount of green biomass compared with that of tobacco and maize, their ability to directly utilize atmospheric nitrogen through nitrogen fixation make them ideal plants for the production of recombinant antibodies and other proteins ( $\mathrm{Ma}$ et al., 2003).

\section{Vegetables and Fruits}

Notably, fruits, vegetables and leafy crops are consumed in the form of moderately processed or entirely raw foods. In addition, these groups of plant products are normally free of toxicants and are rich in nutrients, which make them particularly appropriate for the production of recombinant vaccine subunits, antibodies, and food additives for active immunotherapy (Ma et al., 2003). Potatoes have been used extensively for the production of plant-derived vaccines, which have been administered to humans in many clinical trials. 
Tomato (Lycopersicon esculentum), potato (Solanum tuberosum), banana (Musa acuminata colla) and carrot (Daucus carota spp. sativus) plants have been successfully utilized for the expression of vaccine subunits. Interestingly, among these plants, tomato plants have been utilized as model genetically transformed producers of the first plantderived rabies-vaccine component, HIV-gag and HBsAg proteins (Sala et al., 2003). The accumulation of betaamyloid $(A \beta)$ in the brain initiates the development of Alzheimer's disease (AD), which is a neurodegenerative disease. The accumulation of this toxic protein in the brain can lead to neuronal destruction and intensification of the disease process. Administering an antigen directed against this toxic protein might be the most useful strategy to treat $A D$ or at least to arrest its progress. To this end, scientists have successfully expressed $A \beta$ in tomatoes (Youm et al., 2008). Moreover, thymosin $\alpha 1$ has been expressed in tomato fruits through Agrobacterium-mediated transformation, and this recombinant protein also been used to treat cancer and viral infections (Cheng et al., 2003). The potato plant, which is another member of the Solanaceae family, has attracted the attention of researchers wishing to produce plant-based recombinant proteins. Ma et al. (2003) demonstrated that the potato tuber is a suitable host for the production of diagnostic antibody-fusion proteins, human milk proteins, and other antibodies. Banana plants have been considered as green bioreactors for the production of recombinant antibodies and vaccines. The transgenic fruits of different varieties of banana commonly grown in countries in which vaccines are most desperately needed can be consumed as raw materials by both children and adults or the vaccine subunits within them can be purified (Ma et al., 2003). The specific potential of carrots for plant engineering have led to this plant becoming an ideal candidate for tissue culture and genetic transformation, as well as for plant molecular farming (Muller et al., 2003).

Celery cabbage (Brassica rapa var. pekinensis), lettuce (Lactuca sativa), and cauliflower (Brassica oleracea var. botrytis) are other vegetables that have been considered for plant molecular farming application, although their low regeneration rates and recombinant expression levels remain challenging (Tacket and Mason, 1999).

\section{Oilseeds}

Plants bearing seeds that are rich in oil are known as oilseed plants. Safflower, coconut, peanut, sunflower, palm, sesame, olive, rapeseed and rice (bran) are examples of oilseed plants (Moloney et al., 2003). Safflower and rapeseed have been employed as useful sources of recombinant proteins due to their protein-production capability and the simplicity of purifying the proteins they produce. In addition to the low cost and low acreage associated with their use, the high protein yield obtained and their being self-pollinating plants are other advantages of these oilseed organisms. To produce recombinant proteins in such organisms, scientists exploited oleosin proteins, which are structural components of safflower cells. Oleosins are small structural proteins that are attached to the surface of oil bodies and subcellular organelles that store oils. Oleosin-recombinant fusion proteins must be detached so that they can be extracted, which can be achieved using a simple procedure, namely, endoprotease digestion (Boothe et al., 1997). Safflowerderived insulin and hirudin are new-generation pharmaceutical proteins that have produced by oilseed plants (Spök et al., 2008).

\section{Aquatic plants}

Green-cell factories are also options for plant molecular farming. Aquatic plants are promising green-cell platforms for the introduction of genes and the production of novel recombinant proteins. To this end, the chloroplast and nuclear genomes of five different microalgal species, namely, Cylindrotheca fusifornzis, Symbiodinium microadriaticum, Amphidinium carterae, Pheaeodactylum tricornutu and Chlamydomonas reinhardtii, have been successfully transformed. Among the above-mentioned algal species, Chlamydomonas reinhardtii is the most suitable host for the production of edible vaccine subunits (Potvin and Zhang, 2010; Rasala et al., 2010), antibodies (Mayfield and Franklin, 2005), blood proteins (Manuell et al., 2007), industrial phytases (Yoon et al., 2011), and a growth factor within chloroplasts (Rasala et al., 2010). Their lack of toxicity, low expression levels, low cost, short growth period, high yield and capability for fresh use are the most significant advantages of employing microalgae to overcome the current obstacles in plant molecular farming (Pryer et al., 2002; Zaslavskaia et al., 2000).

Another reliable plant bioreactor for the production of pharmaceutical products is duckweed. Duckweed is a monocotyledonous plant belonging to the Lemnaceae family, which includes four major subspecies, namely, Wolffiella, Spirodela, Lemna and Wolffia (Zhang et al., 2010). Like other plant bioreactors, duckweed has many advantages for the production of recombinant proteins (Stomp, 2005). Some of specific features of this plant are that it is fast-growing, easy to harvest, safe, accumulates high levels of protein, and can produce complex proteins (Popov et al., 2006). Agrobacterium tumefaciens and biolistics are the main methods used to transfer genes to duckweed, such in the case for other plants. Interferon $\alpha 2$ (De Leede et al., 2008), avian influenza H5N1 hemagglutinin ( $\mathrm{Gu}$ and Glatz, 2007), aprotinin (Rival et al., 2008), anti-CD20 mAb (BLX-301), human plasmin (BLX-155) (Paul and Ma, 2011), a monoclonal antibody (Cox et al., 2006) and plasminogen (Spencer et al., 2011) are some of the recombinant proteins that have been produced at various levels by duckweed (Stomp, 2005; Vunsh et al., 2007).

\section{Glycosylation as a modification mechanism in transgenic plants}

Modifying recombinant proteins through post-translational processes plays an important role in their functions. Posttranslational modifications, such as glycosylation, phosphorylation, sulphation and methylation, are vital in transgenic higher eukaryotic organisms (Gomord et al., 2004). One of the most important post-translational modifications is glycosylation. Certain aspects of this enzymatic process, in which glycans are attached to organic molecules such as proteins and lipids, are significantly different in plants and mammalian cells. The 
basic $\mathrm{N}$-acetyl glucosamine (GlcNAc)-mannose precursor structures added to the glycosylation sites of proteins within the endoplasmic reticulum of plant and mammalian cells are identical, but evolution of the Golgi apparatus has caused considerable variation. Glycosylation affects the basic biological functions of proteins, such as their ligandreceptor interactions, specific activity and immunogenicity. A chain of oligosaccharides can be formed via either O- or $\mathrm{N}$-linked glycosylation. $\mathrm{N}$-linked glycosylation occurs within the endoplasmic reticulum (ER), and the primary oligosaccharide chain is further processed during its exit from the ER and passage through the Golgi apparatus (GA) (Balen et al., 2006).

Recent reports concerning glycosylation within transgenic plants suggested that the pattern of glycosylation of an Fc antibody did not have a large effect on antibody-dependent cellular cytotoxicity (ADCC) or the stimulation of the complement cascade. However, four aspects are worth mentioning in relation to the potential effects of adding carbohydrate moieties and replacing them are the following: a) the immunogenicity of plant $\mathrm{N}$-glycans per se, b) the immunogenicity of plant $\mathrm{N}$-glycans in the presence of a given glycoprotein, c) probable allergies to plant $\mathrm{N}$-glycans, and d) the impact of these carbohydrate moieties on pharmacokinetics (Pujol et al., 2007). A general problem is that some antibodies are not produced against compounds consisting of a large number of monosaccharides "linked glycosidically", when inoculated with plant-based enzymes. The best example of this phenomenon is the antagonistic reaction of $\mathrm{N}$-glycans with horseradish peroxidase. In addition, these antibodies interact with glycoproteins from plants, insects and snails that contain the same $\alpha(1,3)$-fucose and $\beta(1,2)$-xylose glycoepitopes (Chargelegue et al., 2000). Unfortunately, the products of plant glycosylation can occasionally lead to side effects, such as allergic reactions. Because persons who are prone to pollen allergies have $\operatorname{lgE}$ (Ig: insoluble glycoproteins) and IgG4 reactivity to glycoepitopes, it is rational to attribute the allergenicity of plant-based glycosylated antibodies to the existence of allergenic factors, such as glycoproteins containing $\alpha(1,3)$-fucose and $\beta(1,2)$-xylose. An appropriate example is the allergenic factors of olive-tree pollens, which contain a glycoprotein with $\alpha(1,3)$-fucose and $\beta(1,2)$-xylose groups that are capable of inducing histamine release by basophils (Cárdaba et al., 2000). Therefore, it may be impossible to predict the side effects of plant-based glycosylated antibodies in humans to whom they are administered. Eventually, engineering the $\mathrm{N}$-glycosylation processes of plants will enhance the efficacy of plant-made pharmaceuticals (PMPs) not only regarding the immunogenicity of $\mathrm{N}$-glycans in humans but also through generating glycovariants of therapeutic proteins with a higher bioactivity levels than those produced in cultured mammalian cells (Saint-Jore-Dupas et al., 2007). In this regard, priority should be given to antibodies containing a single major $\mathrm{N}$-glycan species and lacking detectable levels of plant-specific $N$-glycans (Cárdaba et al., 2000). Such antibodies have been shown to induce better antibody dependent cell-mediated cytotoxicity, demonstrating the potential of plants as systems for the expression of highly demanded anti-cancer antibodies (Cox et al., 2006).

\section{The effect of environmental factors on transgenic plants}

The effects of environmental factors on the health, biomass production and activity of plants are matters of concern even under normal conditions; however, these factors become more serious concerns during the posttransformational period. Indeed, genetically transformed plants are extremely susceptible to the effects of environmental factors immediately after being transferring to natural soil. Environmental condition directly affects the quality and quantity of recombinant proteins produced. The factors that may negatively affect transgenic plants are divided into biotic and abiotic stresses. In this regards, light, drought, salinity, nutritional deficits and cold have negative effects on plant products. These factors are abiotic stresses (Jamal et al., 2009). Light plays a crucial role in regulating photosynthesis and the phenological events that drive the growth and development of plants toward the flowering stage (Dahl et al., 1995). Generally, plants use light of $400-$ and $740-\mathrm{nm}$ wavelengths to conduct photosynthesis. Light of these wavelengths is called photosynthetically active radiation. Photons of wavelengths lower and higher than this range are either impractical or destructive for photosynthesis due to their insufficient or extremely high energy levels (Zhu et al., 2008). To protect recombinant proteins against stresses, scientists try to optimize the light condition, such as the length of the day and the light intensity. Other stresses, such as drought, restrict the establishment of crops. This stress decreases the productivity and quality of plants and leads to morphological changes. Consequently, the expression of recombinant proteins may be downregulated. Similar to the effects of other stresses, drought leads to the accumulation of reactive oxygen species (ROS) in plants, causing oxidative stress (Pastori and Foyer, 2002). Moreover, physiological traits, such as the carbon-assimilation and stomatal-conductance rates are prominent determinants of fitness under drought conditions due to their relevance to the efficiency of water-use and photosynthesis (Heschel and Riginos, 2005). Another restricting factor of plant molecular farming is salinity. Approximately one-third of the world's irrigated farms are ineffective due to the excess salt content of the soil (Munns, 2005). The adverse effects of salt on plants are manifested in two ways. Firstly, a high concentration of salt in the soil directly hampers water absorption by the roots by affecting root-soil osmotic regulation. Secondly, salt accumulation in various organs poisons plants (Munns and Tester, 2008). The two toxic ions derived from $\mathrm{NaCl}, \mathrm{Na}^{+}$ and $\mathrm{Cl}^{-}$, can damage plant cells through both osmotic and ionic mechanisms (Chinnusamy et al., 2005). Quantitative and qualitative changes in metabolite synthesis, as well as the occurrence of enhanced metabolic toxicity are a few of the most usual indicators of stressed plants (Karimi et al., 2005). Furthermore, salt stress alters the expression of cell-cycle progression genes through affecting mitotic cell division (Burssens et al., 2000). All of these cellular processes may be affected by altered hormonal homeostasis occurring under salt-stress conditions (Lee et 
al., 2001). It has been well documented that the abscisic acid (ABA) content of plants increases under salt-stress conditions (Bray, 2002). Adaptation to saline stress is accompanied by alterations in the level of numerous metabolites, proteins, and mRNAs (García et al., 1997). A variety of genes, the expression of which is activated in response to salt stress, have been identified and have been transferred to plants (Rensink et al., 2005). Because high salinity conditions promote plant-cell dehydration (Liu et al., 2011), many of the genes that are activated by saline stress are also activated by drought. The expression of the majority of these genes is regulated by abscisic acid (ABA), a plant hormone that is generated in response to saline stress (Wilkinson and Davies, 2002).

Another important environmental factor that affects plant growth and productivity is temperature. Hightemperature stress induces certain physiological, biochemical, and genetic changes in plants, including protein denaturation, lipid liquefaction, and perturbation of membrane integrity (Levitt, 1980). Among the suppositions regarding high-temperature acclimation are that several mechanisms of adaptation to high temperature involving the induction of protein synthesis or altered protein functions may exist (Turner et al., 2001). High temperatures decrease the rate of synthesis of normal cellular proteins and induce the synthesis of heat-shock proteins (Parsell and Lindquist, 1993). High temperatures are harmful to plant cells, leading to a loss of viability. In Medicago sativa transgenic plants, heat can inactivate the gene that encodes the phosphinothricin/Nacetyltransferase recombinant protein (Walter et al., 1992). Sometimes, transferring plants to an environment with a stressful heat level initiates the expression of members of heat-shock protein/chaperone cascades that prevent the misfolding, denaturation and aberrant aggregation of cellular proteins (Wang et al., 2004). Plants lacking temperature adaptation may be incapable of inducing structural or functional changes in their proteins. According to Stevens et al. (Stevens et al., 2000), exposure to $25^{\circ} \mathrm{C}$ and high light conditions can increase the biomass and total soluble protein content of plants, whereas exposure to high light conditions and $15^{\circ} \mathrm{C}$ favoured the production of a recombinant monoclonal antibody by transgenic tobacco plants.

The temperature also affects the glycosylation of recombinant proteins (antibodies) in plants. Sulphur (S) is a major component of any protein molecule; hence, its uptake and assimilation can affect the production of recombinant proteins in transgenic plants. Of course, $S$ uptake is dependent upon a constant supply of the precursor of cysteine, O-acetylserine, which in turn, is dependent on the presence of adequate nitrogen and carbon sources (Kopriva and Rennenberg, 2004). As a good example, the combined application of $\mathrm{S}$ and $\mathrm{N}$ affects the accumulation of lipids in rapeseed (Brassica napus L.) via the induced increase in the rate of protein synthesis (Fazli et al., 2005). The significantly positive correlation of the antibody and total protein contents of transgenic plants allows the prediction of the fluctuating trend of antibody accumulation through monitoring changes in the amounts of total protein. The above-mentioned facts suggest that providing balanced nutrition would enhance the production of pharmaceutical proteins by transgenic plants.

Large-scale transient gene transfection, climate riskfree production systems, and biosafety considerations Plant biotechnology typically relies on two strategies for delivery and expression of heterologous genes in plants, including a) stable genetic transformation, and b) transient expression using viral vectors (Marillonnet et al., 2005). In recent years, the technological progression in virus-based vectors has allowed plants to become a feasible platform for recombinant proteins (RPs) production, while RPs were only able to be produced from cultures of mammalian, insect, and bacteria cells, previously. The plant-based RPs are more preferable in terms of versatility, speed, cost, scalability, and safety over the current production paradigms (Chen and Lai, 2014). In spite of being a faster method, the transient approach is hampered by low contagiosity of viral vectors carrying average- or largesized genes. Fortunately, these drawbacks have been subject to troubleshooting by developing constructs for the efficient delivery of RNA viral vectors as DNA precursors. The mentioned efforts have tended to expanding systemic Agrobacterium tumefaciens-mediated transfection of viral replicons for efficient transient expression in plants. As such, Agrobacterium-mediated delivery of the target constructs using results in gene amplification in all developed leaves of a plant simultaneously. This process is also referred to as "magnifection" that can be performed on a large scale and with different plant species. The mentioned technique incorporates advantages of three biological systems consisting of: a) the transfection efficiency of $A$. tumefaciens, b) the high expression yield obtained with viral vectors, and c) the post-translational capabilities of a plant. This procedure does not entail genetic modification of plants and is faster than other current methods (Marillonnet et al., 2005).-Transient expression systems have been established to eliminate the long-time frame of generating transgenic plants, so that the transgene is not integrated into the plant genome but rather quickly directs the production of the RP while residing transiently within the plant cell. In addition to the significant acceleration of production timeline, this approach improves the recombinant proteins accumulation level by excluding the "position effect" of variable expression instigated by the random integration of transgene within the genome (Komarova et al., 2010). In another word, the climate riskfree molecular farming systems have become more achievable by conducting the transient gene transfection.

Beside all these advances achieved by the transient expression technology, some complementary strategies have been taken into consideration to limit the potential environmental and human health impacts linked to PMF. Specifically, cell cultures of transgenic plants, physical containment, dedicated land, plastid transformation, biological confinement, male sterility, gene use restriction technologies (GURTs), expression from or in roots, expression in edible parts and seeds, post-harvest inducible expression, and temporal confinement have been suggested as additional solutions to minimize the risks of PMF (Breyer et al., 2009). 
Industrialization, current status and perspectives

As plant molecular farming has come of age, there have been technological progresses on many aspects, including transformation methods, regulating gene expression, protein targeting and accumulation, as well as the use of different crops as production platforms (Twyman et al., 2003). Recently, plant molecular farming has been proposed as an example of a green development scheme in convergence with sustainable agricultural industries. Despite, the yield improvement remains as one of the most challenging issues, because the product yield has a significant impact on economic feasibility of any related project.

The advantages of transgenic plants over other expression systems make them become industrialized as economic alternatives to the conventional pharmaceutics. Several plant-made pharmaceuticals, including the enzyme glucocerebrosidase (GCase), insulin and Interferon alfa $2 b$ [IFN-alpha (2b)], have approached commercialization with low costs and large-scale production. Interestingly, these achievements have been attached to substantial patenting activities as well. Reportedly, there was a tangible downward trend in the number of patents filed from 2002 to 2008 , and a greater number of patents were filed by public sector institutions or inventors than by the private sector (Drake and Thangaraj, 2010). The USA dominated patenting activity providing nearly $30 \%$ of inventors. Most of the patents were related to vaccine candidates $(55 \%)$, followed by therapeutics and antibodies with 38 and $7 \%$, respectively (Drake and Thangaraj, 2010).

\section{Conclusions}

Plant molecular farming has been shown to be a promising biotechnological approach; however, because this approach is novel, its efficacy may be disputed. Methods that facilitate plant cultivation under extremely controlled conditions should be developed for the subsequent stages of this process, as we move away from aseptic plant-cell cultures to non-aseptic conditions in which plants are grown traditionally or are grown hydroponically using compost. Plant molecular farming has significant potential for the development of medicinal products. With regard to the history of plant molecular farming, the current major focus is to accelerate the improvement of plant biotechnological procedures for the generation of new products, as well as conventional products. The most important challenges in this field are identifying new plant resources and optimizing protocols for producing high levels of recombinant proteins. The cryptic medicinal plant such as Andrographis paniculata (Valdiani et al., 2013) can be introduced as an impending candidates (Valdiani et al., 2012), while the genetic (Valdiani et al., 2014), and proteomic (Talei et al., 2014) analyses of the herb have both performed promising horizons for being subjected to plant molecular farming.

\section{Acknowledgements}

The authors would like to appreciate the Long-term Research Grants Scheme (LRGS), Food Security Rice Research Program of the Ministry of Higher Education, Malaysia, for creating an opportunity to conduct the present review article.

\section{References}

Acquaah, G. (2009). Principles of plant genetics and breeding, $1^{\text {th }}$ edn. (John Wiley \& Sons).

Ahmad, K. (2014). Molecular farming: Strategies, expression systems and bio-safety considerations. Czech J. Genet. Plant Breed. 50, 1-10.

Alam, I., Sharmin, S. A., Naher, K., Alam, J., Anisuzzaman, M., and Alam, M. F. (2010). Effect of growth regulators on meristem culture and plantlet establishment in sweet potato [Ipomoea batatas (L.) Lam.]. Plant Omics. 3, 35.

Alam, I., Sharmin, S.A., Naher, K., Alam, J., Anisuzzaman, M., and Alam, M.F. (2010). effect of growth regulators on meristem culture and plantlet establishment in sweet potato [Ipomoea Batatas (L.) Lam.]. Plant Omics 3, 35.

Almquist, K.C., McLean, M.D., Niu, Y., Byrne, G., OleaPopelka, F.C., Murrant, C., Barclay, J., and Hall, J.C. (2006). Expression of an anti-botulinum toxin $A$ neutralizing single-chain $\mathrm{Fv}$ recombinant antibody in transgenic tobacco. Vaccine 24, 2079-2086.

Amrolia, P.J., Cunningham, J.M., Ney, P., Nienhuis, A.W., and Jane, S.M. (1995). Identification of two novel regulatory elements within the 5 '-untranslated region of the human-globin gene. J. Biol. Chem. 270, 12892-12898.

An, C. H., Lee, K. W., Lee, S. H., Jeong, Y. J., Woo, S. G., Chun, H., and Kim, C. Y. (2015). Heterologous expression of IbMYB1a by different promoters exhibits different patterns of anthocyanin accumulation in tobacco. Plant Physiol. Biochem. 89, 1-10.

Anzai, H., Takaiwa, F., Katsumata, K., Shimazaki, K., Tsuda, H., Tomita, M., Kuwata, T., and Perraudin, J. (2000). Production of human lactoferrin in transgenic plants. Paper presented at: Lactoferrin: structure, function and applications. Proceedings of the $4^{\text {th }}$ International Conference on Lactoferrin: Structure, Function and Applications. Sapporo, Japan 18-22 May 1999.

Ashraf, M., Athar, H., Harris, P., and Kwon, T. (2008). Some prospective strategies for improving crop salt tolerance. Adv Agron. 97, 45-110.

Azhakanandam, K., Weissinger, S.M., Nicholson, J.S., Qu, R., and Weissinger, A.K. (2007). Amplicon-plus targeting technology (APTT) for rapid production of a highly unstable vaccine protein in tobacco plants. Plant Mol. Biol. 63, 393-404.

Balen, B., Krsnik-Rasol, M., Zamfir, A.D., Miloševic, J., Vakhrushev, S.Y., and Peter-Katalinic, J. (2006). Glycoproteomic survey of Mammillaria gracillis tissues grown in vitro. J. Proteome Res. 5, 1658-1666.

Barta, A., Sommergruber, K., Thompson, D., Hartmuth, K., Matzke, M.A., and Matzke, A.J. (1986). The expression of a nopaline synthase-human growth hormone chimaeric gene in transformed tobacco and sunflower callus tissue. Plant Mol. Biol. 6, 347-357.

Benchabane, M., Goulet, C., Rivard, D., Faye, L., Gomord, V., and Michaud, D. (2008). Preventing unintended proteolysis in plant protein biofactories. Plant Biotechnol. J. 6, 633-648.

Bock, R. (2007). Plastid biotechnology: prospects for herbicide and insect resistance, metabolic engineering and molecular farming. Curr. Opin. Biotechnol. 18, 100-106. 
Boothe, J.G., Saponja, J.A., and Parmenter, D.L. (1997). Molecular farming in plants: oilseeds as vehicles for the production of pharmaceutical proteins. Drug Dev. Res. 42, 172-181.

Brandsma, M., Wang, X., Diao, H., Kohalmi, S., Jevnikar, A., and Ma, S. (2009). A proficient approach to the production of therapeutic glucagon-like peptide-1 (GLP-1) in transgenic plants. Open Biotechnol J 3, 57-66.

Bray, E. (2002). Abscisic acid regulation of gene expression during water-deficit stress in the era of the Arabidopsis genome. Plant, Cell Environ. 25, 153-161.

Bregitzer, P., and Brown, R.H. (2013). Long-term assessment of transgene behavior in barley: Dsmediated delivery of bar results in robust, stable, and heritable expression. In Vitro Cell. Dev. Biol. -Plant 49, 231-239.

Breyer, D., Goossens, M., Herman, P., and Sneyers, M. (2009). Biosafety considerations associated with molecular farming in genetically modified plants. J. Med. Plants Res. 3, 825-838.

Brodzik, R., Glogowska, M., Bandurska, K., Okulicz, M., Deka, D., Ko, K., van der Linden, J., Leusen, J.H., Pogrebnyak, N., and Golovkin, M. (2006). Plant-derived anti-Lewis $Y$ mAb exhibits biological activities for efficient immunotherapy against human cancer cells. Proc. Natl. Acad. Sci. U. S. A. 103, 8804-8809.

Burana, C., Kurokura, T., Yamaki, Y., and Yamane, K. (2014). Modified atmosphere (MA) and 1methylcyclopropene (1-MCP) combination treatment extends the postharvest life of carnations. Environ. Control Biol. 52, 131-136.

Burssens, S., Himanen, K., Van De Cotte, B., Beeckman, T., Van Montagu, M., Inzé, D., and Verbruggen, N. (2000). Expression of cell cycle regulatory genes and morphological alterations in response to salt stress in Arabidopsis thaliana. Planta 211, 632-640.

Cai, S., Jiang, G., Ye, N., Chu, Z., Xu, X., Zhang, J., and Zhu, G. (2015). A key ABA catabolic gene, OsABA8ox3, is involved in drought stress resistance in rice. Plos One 10, e0116646.

Cárdaba, B., Cortegano, I., Florido, F., Arrieta, I., Aceituno, E., Del Pozo, V., Gallardo, S., Rojo, M., Palomino, P., and Lahoz, C. (2000). Genetic restrictions in olive pollen allergy. J. Allergy Clin. Immunol. 105, 292-298.

Chan, M.-T., Chang, H.-H., Ho, S.-L., Tong, W.-F., and Yu, S.-M. (1993). Agrobacterium-mediated production of transgenic rice plants expressing a chimeric $\alpha$-amylase promoter/ $\beta$-glucuronidase gene. Plant Mol. Biol. 22, 491-506.

Chargelegue, D., Vine, N.D., van Dolleweerd, C.J., Drake, P.M., and Ma, J.K. (2000). A murine monoclonal antibody produced in transgenic plants with plant-specific glycans is not immunogenic in mice. Transgenic Res. 9, 187-194.

Chen, Q. (2008). Expression and purification of pharmaceutical proteins in plants. J. Biol. Eng. 1, 291-321.

Chen, Q., and Lai, H. (2014). Gene delivery into plant cells for recombinant protein production. BioMed Res. Int. doi: $10.1155 / 2014 / 932161$
Cheng, M., Hu, T., Layton, J., Liu, C.-N., and Fry, J.E. (2003). Desiccation of plant tissues post-Agrobacterium infection enhances T-DNA delivery and increases stable transformation efficiency in wheat. In Vitro Cell. Dev. Biol. -Plant 39, 595-604.

Chinnusamy, V., Jagendorf, A., and Zhu, J.-K. (2005). Understanding and improving salt tolerance in plants. Crop Sci. 45, 437-448.

Chugh, A., Eudes, F., and Shim, Y.-S. (2010). Cellpenetrating peptides: Nanocarrier for macromolecule delivery in living cells. IUBMB Life 62, 183-193.

Condliffe, P. C., Davey, M. R., Brian Power, J., Koehorstvan Putten, H., and Visser, P. B. (2003). An optimized protocol for rose transformation applicable to different cultivars. In: XXI International Eucarpia Symposium on Classical versus Molecular Breeding of OrnamentalsPart I. 612, 115-120.

Costanzo, M.C., and Fox, T.D. (1995). A point mutation in the 5 '-untranslated leader that affects translational activation of the mitochondrial COX 3 mRNA. Curr. Genet. 28, 60-66.

Cox, K.M., Sterling, J.D., Regan, J.T., Gasdaska, J.R., Frantz, K.K., Peele, C.G., Black, A., Passmore, D., Moldovan-Loomis, C., and Srinivasan, M. (2006). Glycan optimization of a human monoclonal antibody in the aquatic plant Lemna minor. Nat. Biotechnol. 24, 1591-1597.

Curie, C., and McCormick, S. (1997). A strong inhibitor of gene expression in the 5'untranslated region of the pollen-specific LAT59 gene to tomato. Plant Cell 9, 2025-2036.

da Cunha, N.B., Vianna, G.R., da Almeida Lima, T., and Rech, E. (2014). Molecular farming of human cytokines and blood products from plants: Challenges in biosynthesis and detection of plant produced recombinant proteins. Biotechnol. J. 9, 39-50.

Dahl, M.-L., Johansson, I., Bertilsson, L., IngelmanSundberg, M., and Sjöqvist, F. (1995). Ultrarapid hydroxylation of debrisoquine in a Swedish population. Analysis of the molecular genetic basis. J. Pharmacol. Exp. Ther. 274, 516-520.

Datla, R.S., Bekkaoui, F., Hammerlindl, J.K., Pilate, G., Dunstan, D.I., and Crosby, W.L. (1993). Improved highlevel constitutive foreign gene expression in plants using an AMV RNA4 untranslated leader sequence. Plant Sci. 94, 139-149.

De La Fuente, G.N., Frei, U.K., and Lübberstedt, T. (2013). Accelerating plant breeding. Trends Plant Sci. 18, 667-672.

De la Fuente, J.M., Ramírez-Rodríguez, V., CabreraPonce, J.L., and Herrera-Estrella, L. (1997). Aluminum tolerance in transgenic plants by alteration of citrate synthesis. Science 276, 1566-1568.

De Leede, L.G., Humphries, J.E., Bechet, A.C., Van Hoogdalem, E.J., Verrijk, R., and Spencer, D.G. (2008). Novel controlled-release lemna-derived IFN-a $2 b$ (locteron): pharmacokinetics, pharmacodynamics, and tolerability in a phase I clinical trial. J. Interferon Cytokine Res. 28, 113-122.

De Neve, M., De Buck, S., De Wilde, C., Van Houdt, H., Strobbe, I., Jacobs, A., Van Montagu, M., and Depicker, A. (1999). Gene silencing results in instability of antibody 
production in transgenic plants. Mol. Gen. Genet. 260, 582-592.

Denecke, J., De Rycke, R., and Botterman, J. (1992). Plant and mammalian sorting signals for protein retention in the endoplasmic reticulum contain a conserved epitope. EMBO 11, 2345.

Dickey, L.F., Gallo-Meagher, M., and Thompson, W. (1992). Light regulatory sequences are located within the 5 'portion of the Fed-1 message sequence. EMBO 11, 2311.

Dillen, W., Clercq, J., Kapila, J., Zambre, M., Montagu, M., and Angenon, G. (1997). The effect of temperature on Agrobacterium tumefaciens-mediated gene transfer to plants. Plant J. 12, 1459-1463.

Drake, P.M., and Thangaraj, H. (2010). Molecular farming, patents and access to medicines. Expert Rev. Vaccines 9, 811-819. doi: 10.1586/erv.10.72.

Du, Y., Wei, X., Dodel, R., Sommer, N., Hampel, H., Gao, F., Ma, Z., Zhao, L., Oertel, W.H., and Farlow, M. (2003). Human anti $\beta$-amyloid antibodies block $\beta$-amyloid fibril formation and prevent $\beta$-amyloid induced neurotoxicity. Brain 126, 1935-1939.

Dunwell, J.M. (2009). Transgenic wheat, barley and oats: future prospects. In Methods in Molecular Biology, H.D. Jones, and P.R. Shewry, eds. (Humana Press, Springer), pp. 333-345.

Dynkevich, Y., Rother, K.I., Whitford, I., Qureshi, S., Galiveeti, S., Szulc, A.L., Danoff, A., Breen, T.L., Kaviani, N., and Shanik, M.H. (2013). Tumors, IGF-2, and Hypoglycemia: Insights From the Clinic, the Laboratory, and the Historical Archive. Endocr. Rev. 34, 798-826.

Enríquez-Obregón, G.A., Prieto-Samsónov, D.L., Gustavo, A., Pérez, M., Selman-Housein, G., and VázquezPadrón, R.I. (1999). Agrobacterium-mediated Japonica rice transformation: a procedure assisted by an antinecrotic treatment. Plant Cell Tissue Organ Cult. 59, 159-168.

Faye, L., Boulaflous, A., Benchabane, M., Gomord, V., and Michaud, D. (2005). Protein modifications in the plant secretory pathway: current status and practical implications in molecular pharming. Vaccine 23, 1770-1778.

Fazli, I., Abdin, M., Jamal, A., and Ahmad, S. (2005). Interactive effect of sulphur and nitrogen on lipid accumulation, acetyl-CoA concentration and acetyl-CoA carboxylase activity in developing seeds of oilseed crops (Brassica campestris L. and Eruca sativa Mill.). Plant Sci. 168, 29-36.

Fischer, R., Drossard, J., Commandeur, U., Schillberg, S., and Emans, N. (1999). Towards molecular farming in the future: moving from diagnostic protein and antibody production in microbes to plants. Biotechnol. Appl. Biochem. 30, 101-108.

Fischer, R., Schillberg, S., Hellwig, S., Twyman, R. M., \& Drossard, J. (2012). GMP issues for recombinant plantderived pharmaceutical proteins. Biotechnol. Adv. 30, 434-439.

Floss, D.M., Falkenburg, D., and Conrad, U. (2007). Production of vaccines and therapeutic antibodies for veterinary applications in transgenic plants: an overview. Transgenic Res. 16, 315-332.
Franconi, R., Demurtas, O.C., and Massa, S. (2010). Plantderived vaccines and other therapeutics produced in contained systems. Expert Rev. Vaccines 9, 877-892.

Gallie, D.R., and Kobayashi, M. (1994). The role of the 3'untranslated region of non-polyadenylated plant viral mRNAs in regulating translational efficiency. Gene 142, 159-165

García, M.J., Ríos, G., Ali, R., Bellés, J.M., and Serrano, R. (1997). Comparative physiology of salt tolerance in Candida tropicalis and Saccharomyces cerevisiae. Microbiology 143, 1125-1131.

Gebauer, F., and Hentze, M.W. (2004). Molecular mechanisms of translational control. Nat. Rev. Mol. Cell Biol. 5, 827-835.

Gelvin, S.B. (2012). Traversing the cell: Agrobacterium TDNA's journey to the host genome. Front. Plant Sci. 3, 52.

George, E.F., Hall, M.A., and De Klerk, G.-J. (2008). Micropropagation: uses and methods, Vol 1, $3^{\text {rd }}$ edn (Dordrecht, The Netherlands: Springer).

Girard, L.S., Fabis, M.J., Bastin, M., Courtois, D., Pétiard, V., and Koprowski, H. (2006). Expression of a human anti-rabies virus monoclonal antibody in tobacco cell culture. Biochem. Biophys. Res. Commun. 345, 602-607.

Gleba, Y., Klimyuk, V., and Marillonnet, S. (2005). Magnifection-a new platform for expressing recombinant vaccines in plants. Vaccine 23, 2042-2048.

Gomord, V., Sourrouille, C., Fitchette, A.C., Bardor, M., Pagny, S., Lerouge, P., and Faye, L. (2004). Production and glycosylation of plant made pharmaceuticals: the antibodies as a challenge. Plant Biotechnol. J. 2, 83-100.

Goo, Y. M., Han, E. H., Jeong, J. C., Kwak, S. S., Yu, J., Kim, Y. H., and Lee, S. W. (2015). Overexpression of the sweet potato $\mathrm{lbOr}$ gene results in the increased accumulation of carotenoid and confers tolerance to environmental stresses in transgenic potato. C. R. Biol. 338, 12-20.

Gu, Z., and Glatz, C.E. (2007). A method for threedimensional protein characterization and its application to a complex plant (corn) extract. Biotechnol. Bioeng. 97, 1158-1169.

Guan, C., Li, X., Jin, C., Ji, J., and Wang, G. (2015). LcBiP, an endoplasmic reticulum chaperone binding protein gene from Lycium chinense, confers cadmium tolerance in transgenic tobacco. Biotechnol. Prog. doi: 10.1002/ btpr.2046

Häkkinen, S.T., Raven, N., Henquet, M., Laukkanen, M.L., Anderlei, T., Pitkänen, J.P., Twyman, R.M., Bosch, D., Oksman-Caldentey, K.M., and Schillberg, S. (2014). Molecular farming in tobacco hairy roots by triggering the secretion of a pharmaceutical antibody. Biotechnol. Bioeng. 111, 336-346.

Han, M., SU, T., ZU, Y.-G., and AN, Z.-G. (2006). Research advances on transgenic plant vaccines. Acta Genet. Sin. 33, 285-293.

Heschel, M.S., and Riginos, C. (2005). Mechanisms of selection for drought stress tolerance and avoidance in Impatiens capensis (Balsaminaceae). Am. J. Bot. 92, 37-44. 
Hiatt, A., and Pauly, M. (2006). Monoclonal antibodies from plants: a new speed record. Proc. Natl. Acad. Sci. U. S. A. 103, 14645-14646.

Hiei, Y., Komari, T., and Kubo, T. (1997). Transformation of rice mediated by Agrobacterium tumefaciens. Plant Mol. Biol. 35, 205-218.

Hirsch, R.E., and Sussman, M.R. (1999). Improving nutrient capture from soil by the genetic manipulation of crop plants. Trends Biotechnol. 17, 356-361.

Hood, E.E. (2002). From green plants to industrial enzymes. Enzyme Microb. Technol. 30, 279-283.

Hood, E.E., Love, R., Lane, J., Bray, J., Clough, R., Pappu, K., Drees, C., Hood, K.R., Yoon, S., and Ahmad, A. (2007). Subcellular targeting is a key condition for highlevel accumulation of cellulase protein in transgenic maize seed. Plant Biotechnol. J. 5, 709-719.

Horn, M., Woodard, S., and Howard, J. (2004). Plant molecular farming: systems and products. Plant Cell Rep. 22, 711-720.

Huang, T.K., Plesha, M.A., Falk, B.W., Dandekar, A.M., and McDonald, K.A. (2009). Bioreactor strategies for improving production yield and functionality of a recombinant human protein in transgenic tobacco cell cultures. Biotechnol. Bioeng. 102, 508-520.

Hull, A.K., Criscuolo, C.J., Mett, V., Groen, H., Steeman, W., Westra, H., Chapman, G., Legutki, B., Baillie, L., and Yusibov, V. (2005). Human-derived, plant-produced monoclonal antibody for the treatment of anthrax. Vaccine 23, 2082-2086.

Ikeuchi, M., Sugimoto, K., and Iwase, A. (2013). Plant callus: mechanisms of induction and repression. Plant Cell 25, 3159-3173.

Jamal, A., Ko, K., Kim, H.-S., Choo, Y.-K., Joung, H., and Ko, K. (2009). Role of genetic factors and environmental conditions in recombinant protein production for molecular farming. Biotechnol. Adv. 27, 914-923.

Jani, D., Singh, N., Bhattacharya, S., Meena, L., Singh, Y., Upadhyay, S., Sharma, A., and Tyagi, A. (2004). Studies on the immunogenic potential of plant-expressed cholera toxin B subunit. Plant Cell Rep. 22, 471-477.

Johnston, R.J., Poholek, A.C., DiToro, D., Yusuf, I., Eto, D., Barnett, B., Dent, A.L., Craft, J., and Crotty, S. (2009). Bcl6 and Blimp-1 are reciprocal and antagonistic regulators of $\mathrm{T}$ follicular helper cell differentiation. Science 325, 1006-1010.

Kamenarova, K., Abumhadi, N., Gecheff, K., \& Atanassov, A. (2005). Molecular farming in plants: an approach of agricultural biotechnology. J. Cell Mol. Biol. 4, 77-86.

Kamenarova, K., Abumhadi, N., Gecheff, K., and Atanassov, A. (2005). Molecular farming in plants: an approach of agricultural biotechnology. J. Cell Mol. Biol. 4, 77-86.

Karg, S.R., and Kallio, P.T. (2009). The production of biopharmaceuticals in plant systems. Biotechnol. Adv. 27, 879-894.

Karimi, G., Ghorbanli, M., Heidari, H., Nejad, R.K., and Assareh, M. (2005). The effects of $\mathrm{NaCl}$ on growth, water relations, osmolytes and ion content in Kochia prostrata. Biol. Plant. 49, 301-304.

Karimi, M., Inzé, D., Van Lijsebettens, M., and Hilson, P. (2013). Gateway vectors for transformation of cereals. Trends Plant Sci. 18, 1-4.
Kavitah, G., Taghipour, F., and Huyop, F. (2010). Investigation of factors in optimizing Agrobacteriummediated gene transfer in Citrullus lanatus cv. Round Dragon. J. Biol. Sci. 10, 209-216.

Kervestin, S., and Amrani, N. (2004). Translational regulation of gene expression. Genome Biol. 5, 359.

Kidokoro, S., Watanabe, K., Ohori, T., Moriwaki, T., Maruyama, K., Mizoi, J., Myint Nang, P. S. H., Sachiko S., Kazuo, S., and Yamaguchi-Shinozaki, K. (2015). Soybean DREB1/CBF-type transcription factors function in heat and drought as well as cold stress-responsive gene expression. Plant J. 81, 505-518.

Kim, H., Lee, K., Hwang, H., Bhatnagar, N., Kim, D. Y., Yoon, I. S., Byun, M. O., Kim, S. T., Jung, K. H., and Kim, B. G. (2014). Overexpression of $P Y L 5$ in rice enhances drought tolerance, inhibits growth, and modulates gene expression. J. Exp. Bot. 65, 453-464.

Kim, T.-G., Baek, M.-Y., Lee, E.-K., Kwon, T.-H., and Yang, M.-S. (2008). Expression of human growth hormone in transgenic rice cell suspension culture. Plant Cell Rep. 27, 885-891.

Kleiner, S. (1995). The true nature of herbs. Physician Sportsmed. 23, 13-14.

Ko, K., Norelli, J.L., Reynoird, J.-P., Boresjza-Wysocka, E., Brown, S.K., and Aldwinckle, H.S. (2000). Effect of untranslated leader sequence of AMV RNA 4 and signal peptide of pathogenesis-related protein $1 \mathrm{~b}$ on attacin gene expression, and resistance to fire blight in transgenic apple. Biotechnol. Lett. 22, 373-381.

Ko, K., Steplewski, Z., Glogowska, M., and Koprowski, H. (2005). Inhibition of tumor growth by plant-derived mAb. Proc. Natl. Acad. Sci. U. S. A. 102, 7026-7030.

Ko, K., Tekoah, Y., Rudd, P.M., Harvey, D.J., Dwek, R.A., Spitsin, S., Hanlon, C.A., Rupprecht, C., Dietzschold, B., and Golovkin, M. (2003). Function and glycosylation of plant-derived antiviral monoclonal antibody. Proc. Natl. Acad. Sci. U. S. A. 100, 8013-8018.

Koornneef, M., and Meinke, D. (2010). The development of Arabidopsis as a model plant. Plant J. 61, 909-921.

Komarova, T. V., Baschieri, S., Donini, M., Marusic, C., Benvenuto, E., and Dorokhov, Y. L. (2010). Transient expression systems for plant-derived biopharmaceuticals. Expert Rev. Vaccines 9, 859-876.

Kopriva, S., and Rennenberg, H. (2004). Control of sulphate assimilation and glutathione synthesis: interaction with $\mathrm{N}$ and $\mathrm{C}$ metabolism. J. Exp. Bot. 55, 1831-1842.

Koya, V., Moayeri, M., Leppla, S.H., and Daniell, H. (2005). Plant-based vaccine: mice immunized with chloroplastderived anthrax protective antigen survive anthrax lethal toxin challenge. Infect. Immun. 73, 8266-8274.

Krivosheeva, A. B., Varlamova, T. V., Yurieva, N. O., Sobol'kova, G. I., Kholodova, V. P., and Belyaev, D. V. (2014). Potato transformation with the HvNHX3 gene and the improvement of transformant salt tolerance. Russ. J. Plant Physiol. 61, 792-800.

Kumar, D., and Kirti, P. B. (2015). Pathogen-induced SGT1 of Arachis diogoi induces cell death and enhanced disease resistance in tobacco and peanut. Plant Biotechnol. J. 13, 73-84. 
Lau, W., Fischbach, M.A., Osbourn, A., and Sattely, E.S. (2014). Key applications of plant metabolic engineering. Plos Biol. 12, e1001879.

Lee, H., Xiong, L., Gong, Z., Ishitani, M., Stevenson, B., and Zhu, J.-K. (2001). The Arabidopsis HOS1 gene negatively regulates cold signal transduction and encodes a RING finger protein that displays coldregulated nucleo-cytoplasmic partitioning. Genes Dev. 15, 912-924.

Lee, M.Y., Zhou, Y., Lung, R.W., Chye, M.L., Yip, W.K., Zee, S.Y., and Lam, E. (2006). Expression of viral capsid protein antigen against Epstein-Barr virus in plastids of Nicotiana tabacum cV. SR1. Biotechnol. Bioeng. 94, 1129-1137.

Lee, S. H., Li, C. W., Liau, C. H., Chang, P. Y., Liao, L. J., Lin, C. S., and Chan, M. T. (2015). Establishment of an Agrobacterium-mediated genetic transformation procedure for the experimental model orchid Erycina pusilla. Plant Cell Tissue Organ Cult. 120, 211-220.

Lenzi, P., Scotti, N., Alagna, F., Tornesello, M.L., Pompa, A., Vitale, A., De Stradis, A., Monti, L., Grillo, S., and Buonaguro, F.M. (2008). Translational fusion of chloroplast-expressed human papillomavirus type 16 L1 capsid protein enhances antigen accumulation in transplastomic tobacco. Transgenic Res. 17, 1091-1102.

Levitt, J. (1980). Responses of plants to environmental stresses. Volume II. Water, radiation, salt, and other stresses (Academic Press.).

Lienard, D., Dinh, O.T., Van Oort, E., Van Overtvelt, L., Bonneau, C., Wambre, E., Bardor, M., Cosette, P., Didier-Laurent, A., and Borne, D. (2007). Suspensioncultured BY 2 tobacco cells produce and mature immunologically active house dust mite allergens. Plant Biotechnol. J. 5, 93-108.

Liu, X., Hong, L., Li, X.-Y., Yao, Y., Hu, B., and Li, L. (2011). Improved drought and salt tolerance in transgenic Arabidopsis overexpressing a NAC transcriptional factor from Arachis hypogaea. Biosci. Biotechnol. Biochem. 75, 443-450.

Lopes, M., Reynolds, M., Manes, Y., Singh, R., Crossa, J., and Braun, H. (2012). Genetic yield gains and changes in associated traits of CIMMYT spring bread wheat in a "historic" set representing 30 years of breeding. Crop Sci. 52, 1123-1131.

Ma, J., KC Drake, P.M., and Christou, P. (2003). The production of recombinant pharmaceutical proteins in plants. Nat. Rev. Genet. 4, 794-805.

Ma, J.K.-C., Hikmat, B.Y., Wycoff, K., Vine, N.D., Chargelegue, D., Yu, L., Hein, M.B., and Lehner, T. (1998). Characterization of a recombinant plant monoclonal secretory antibody and preventive immunotherapy in humans. Nat. Med. 4, 601-606.

Ma, S., Huang, Y., Yin, Z., Menassa, R., Brandle, J.E., and Jevnikar, A.M. (2004). Induction of oral tolerance to prevent diabetes with transgenic plants requires glutamic acid decarboxylase (GAD) and IL-4. Proc. Natl. Acad. Sci. U. S. A. 101, 5680-5685.

Ma, S.-W., Zhao, D.-L., Yin, Z.-Q., Mukherjee, R., Singh, B., Qin, H.-Y., Stiller, C., and Jevnikar, A. (1997). Transgenic plants expressing autoantigens fed to mice to induce oral immune tolerance. Nat. Med. 3, 793-796.
Magnuson, N.S., Linzmaier, P.M., Reeves, R., An, G., HayGlass, K., and Lee, J.M. (1998). Secretion of biologically active human interleukin- 2 and interleukin- 4 from genetically modified tobacco cells in suspension culture. Protein Expr. Purif. 13, 45-52.

Makvandi-Nejad, S., McLean, M.D., Hirama, T., Almquist, K.C., MacKenzie, C.R., and Hall, J.C. (2005). Transgenic tobacco plants expressing a dimeric single-chain variable fragment (scfv) antibody against Salmonella enterica serotype Paratyphi B. Transgenic Res. 14, 785-792.

Manuell, A.L., Beligni, M.V., Elder, J.H., Siefker, D.T., Tran, M., Weber, A., McDonald, T.L., and Mayfield, S.P. (2007). Robust expression of a bioactive mammalian protein in Chlamydomonas chloroplast. Plant Biotechnol. J. 5, 402-412.

Marillonnet, S., Thoeringer, C., Kandzia, R., Klimyuk, V., and Gleba, Y. (2005). Systemic Agrobacterium tumefaciens-mediated transfection of viral replicons for efficient transient expression in plants. Nat. Biotechnol. 23, 718-723.

Marusic, C., Nuttall, J., Buriani, G., Lico, C., Lombardi, R., Baschieri, S., Benvenuto, E., and Frigerio, L. (2007). Expression, intracellular targeting and purification of HIV Nef variants in tobacco cells. BMC Biotechnol. 7, 12.

Mayfield, S.P., and Franklin, S.E. (2005). Expression of human antibodies in eukaryotic micro-algae. Vaccine 23, 1828-1832.

Mechold, U., Gilbert, C., and Ogryzko, V. (2005). Codon optimization of the BirA enzyme gene leads to higher expression and an improved efficiency of biotinylation of target proteins in mammalian cells. J. Biotechnol. 116, 245-249.

Mewett, O., Johnson, H., and Holtzapffel, R. (2007). Plant molecular farming in Australia and overseas (Bureau of Rural Sciences).

Meyer, M., de Angelis, M.H., Wurst, W., and Kühn, R. (2010). Gene targeting by homologous recombination in mouse zygotes mediated by zinc-finger nucleases. Proc. Natl. Acad. Sci. U. S. A. 107, 15022-15026.

Mitsuhara, I., Ugaki, M., Hirochika, H., Ohshima, M., Murakami, T., Gotoh, Y., Katayose, Y., Nakamura, S., Honkura, R., and Nishimiya, S. (1996). Efficient promoter cassettes for enhanced expression of foregin genes in Dicotyledonous and Monocotyledonous plants. Plant Cell Physiol. 37, 49-59.

Moloney, M., Boothe, J., and Van Rooijen, G. (2003). Oil bodies and associated proteins as affinity matrices (USA: Google Patents).

Muller, C.P., Fack, F., Damien, B., and Bouche, F.B. (2003). Immunogenic measles antigens expressed in plants: role as an edible vaccine for adults. Vaccine $21,816-819$.

Munns, R. (2005). Genes and salt tolerance: bringing them together. New Phytol. 167, 645-663.

Munns, R., and Tester, M. (2008). Mechanisms of salinity tolerance. Annu. Rev. Plant Biol. 59, 651-681.

Murashige, T., and Skoog, F. (1962). A revised medium for rapid growth and bio assays with tobacco tissue cultures. Physiol. Plant 15, 473-497.

Nandi, S., Suzuki, Y.A., Huang, J., Yalda, D., Pham, P., Wu, L., Bartley, G., Huang, N., and Lönnerdal, B. (2002). Expression of human lactoferrin in transgenic rice grains 
for the application in infant formula. Plant Sci. 163, 713-722.

Nanou, A., and Azzouz, M. (2009). Gene therapy for neurodegenerative diseases based on lentiviral vectors. Prog. Brain Res. 175, 187-200.

Nguyen, H.T., Leelavathi, S., and Reddy, V.S. (2004). Bacteriophage T7 RNA polymerase-directed, inducible and tissue-specific over-expression of foreign genes in transgenic plants. Plant Biotechnol. J. 2, 301-310.

Obembe, O.O., Popoola, J.O., Leelavathi, S., and Reddy, S.V. (2011). Advances in plant molecular farming. Biotechnol. Adv. 29, 210-222.

Oey, M., Lohse, M., Kreikemeyer, B., and Bock, R. (2009). Exhaustion of the chloroplast protein synthesis capacity by massive expression of a highly stable protein antibiotic. Plant J. 57, 436-445.

Oliver, M.J., Armstrong, J., and Bewley, J. (1993). Desiccation and the control of expression of $\beta$-phaseolin in transgenic tobacco seeds. J. Exp. Bot. 44, 1239-1244.

Pantaleoni, L., Longoni, P., Ferroni, L., Baldisserotto, C., Leelavathi, S., Reddy, V.S., Pancaldi, S., and Cella, R. (2014). Chloroplast molecular farming: efficient production of a thermostable xylanase by Nicotiana tabacum plants and long-term conservation of the recombinant enzyme. Protoplasma 251, 639-648.

Park, Y., and Cheong, H. (2002). Expression and production of recombinant human interleukin-2 in potato plants. Protein Expr. Purif. 25, 160-165.

Parkin, J., and Cohen, B. (2001). An overview of the immune system. Lancet 357, 1777-1789.

Parsell, D., and Lindquist, S. (1993). The function of heatshock proteins in stress tolerance: degradation and reactivation of damaged proteins. Annu. Rev. Genet. 27, 437-496.

Pastori, G.M., and Foyer, C.H. (2002). Common components, networks, and pathways of cross-tolerance to stress. The central role of "redox" and abscisic acidmediated controls. Plant Physiol. 129, 460-468.

Paul, M., and Ma, J.K.-C. (2011). Plant-made pharmaceuticals: Leading products and production platforms. Biotechnol. Appl. Biochem. 58, 58-67.

Peng, X. C., Quu, D. W., Zeng, H. M., Guo, L. H., Yang, X. F., and Liu, Z. (2015). Inducible and constitutive expression of an elicitor gene Hrip1 from Alternaria tenuissima enhances stress tolerance in Arabidopsis. Transgenic Res. 24, 135-145.

Pérez-Díaz, J., Wu, T. M., Pérez-Díaz, R., Ruíz-Lara, S., Hong, C. Y., and Casaretto, J. A. (2014). Organ-and stress-specific expression of the ASR genes in rice. Plant Cell Rep. 33, 61-73.

Pilsyk, S., Natorff, R., Gawińska-Urbanowicz, H., and Kruszewska, J. S. (2015). Fusarium sambucinum astA gene expressed during potato infection is a functional orthologue of Aspergillus nidulans astA. Fungal Biol. doi: 10.1016/j.funbio.2015.02.002

Pogrebnyak, N., Golovkin, M., Andrianov, V., Spitsin, S., Smirnov, Y., Egolf, R., and Koprowski, H. (2005). Severe acute respiratory syndrome (SARS) S protein production in plants: development of recombinant vaccine. Proc. Natl. Acad. Sci. U. S. A. 102, 9062-9067.

Pogue, G.P., Vojdani, F., Palmer, K.E., Hiatt, E., Hume, S., Phelps, J., Long, L., Bohorova, N., Kim, D., and Pauly, M.
(2010). Production of pharmaceutical-grade recombinant aprotinin and a monoclonal antibody product using plantbased transient expression systems. Plant Biotechnol. J. 8, 638-654.

Popov, S.V., Golovchenko, V.V., Ovodova, R.G., Smirnov, V.V., Khramova, D.S., Popova, G.Y., and Ovodov, Y.S. (2006). Characterisation of the oral adjuvant effect of lemnan, a pectic polysaccharide of Lemna minor $\mathrm{L}$. Vaccine 24, 5413-5419.

Potvin, G., and Zhang, Z. (2010). Strategies for high-level recombinant protein expression in transgenic microalgae: a review. Biotechnol. Adv. 28, 910-918.

Pryer, K.M., Schneider, H., Zimmer, E.A., and Ann Banks, J. (2002). Deciding among green plants for whole genome studies. Trends Plant Sci. 7, 550-554.

Pujol, M., Gavilondo, J., Ayala, M., Rodríguez, M., González, E.M., and Pérez, L. (2007). Fighting cancer with plant-expressed pharmaceuticals. Trends Biotechnol. 25, 455-459.

Rasala, B.A., Muto, M., Lee, P.A., Jager, M., Cardoso, R.M., Behnke, C.A., Kirk, P., Hokanson, C.A., Crea, R., and Mendez, M. (2010). Production of therapeutic proteins in algae, analysis of expression of seven human proteins in the chloroplast of Chlamydomonas reinhardtii. Plant Biotechnol. J. 8, 719-733.

Reddy, V.S., Leelavathi, S., Selvapandiyan, A., Raman, R., Giovanni, F., Shukla, V., and Bhatnagar, R.K. (2002). Analysis of chloroplast transformed tobacco plants with cry1la5 under rice $p s b A$ transcriptional elements reveal high level expression of Bt toxin without imposing yield penalty and stable inheritance of transplastome. Mol. Breed. 9, 259-269.

Rensink, W.A., lobst, S., Hart, A., Stegalkina, S., Liu, J., and Buell, C.R. (2005). Gene expression profiling of potato responses to cold, heat, and salt stress. Funct. Integr. Genomics 5, 201-207.

Rival, S., Wisniewski, J.-P., Langlais, A., Kaplan, H., Freyssinet, G., Vancanneyt, G., Vunsh, R., Perl, A., and Edelman, M. (2008). Spirodela (duckweed) as an alternative production system for pharmaceuticals: a case study, aprotinin. Transgenic Res. 17, 503-513.

Rivera, A.L., Gómez-Lim, M., Fernández, F., and Loske, A.M. (2012). Physical methods for genetic plant transformation. Phys. Life Rev. 9, 308-345.

Rodriguez-Oroz, M., Obeso, J., Lang, A., Houeto, J.-L., Pollak, P., Rehncrona, S., Kulisevsky, J., Albanese, A., Volkmann, J., and Hariz, M. (2005). Bilateral deep brain stimulation in Parkinson's disease: a multicentre study with 4 years follow-up. Brain 128, 2240-2249.

Ruebelt, M.C., Lipp, M., Reynolds, T.L., Astwood, J.D., Engel, K.-H., and Jany, K.-D. (2006). Application of twodimensional gel electrophoresis to interrogate alterations in the proteome of genetically modified crops. 2 . Assessing natural variability. J. Agric. Food Chem. 54, 2162-2168.

Sahebi, M., Hanafi, M.M., Akmar, A.S.N., Rafii, M.Y., Azizi, P., and Idris, A. (2014). Serine rich protein is a novel positive regulator for silicon accumulation in mangrove. Gene 556, 170-81.

Saint-Jore-Dupas, C., Faye, L., and Gomord, V. (2007). From planta to pharma with glycosylation in the toolbox. Trends Biotechnol. 25, 317-323. 
Sala, F., Manuela Rigano, M., Barbante, A., Basso, B., Walmsley, A.M., and Castiglione, S. (2003). Vaccine antigen production in transgenic plants: strategies, gene constructs and perspectives. Vaccine 21, 803-808.

Sankararao, K., and Rohini, V. K. (1999). Gene transfer into Indian cultivars of safflower (Carthamus tinctorius L.) using Agrobacterium tumefaciens. Plant Biotechnol. 16, 201-206.

Schillberg, S., Fischer, R., and Emans, N. (2003). 'Molecular farming'of antibodies in plants. Naturwissenschaften 90, 145-155.

Schillberg, S., Twyman, R.M., and Fischer, R. (2005). Opportunities for recombinant antigen and antibody expression in transgenic plants-technology assessment. Vaccine 23, 1764-1769.

Shaaltiel, Y., Bartfeld, D., Hashmueli, S., Baum, G., BrillAlmon, E., Galili, G., Dym, O., Boldin-Adamsky, S.A., Silman, I., and Sussman, J.L. (2007). Production of glucocerebrosidase with terminal mannose glycans for enzyme replacement therapy of Gaucher's disease using a plant cell system. Plant Biotechnol. J. 5, 579-590.

Sheng, J., and Citovsky, V. (1996). Agrobacterium-plant cell DNA transport: have virulence proteins, will travel. Plant Cell 8, 1699.

Singh, A., Verma, S., and Bansal, K. (2010). Plastid transformation in eggplant (Solanum melongena L.). Transgenic Res. 19, 113-119.

Sood, P., Bhattacharya, A., and Sood, A. (2011). Problems and possibilities of monocot transformation. Biol. Plant $55,1-15$.

Soria-Guerra, R.E., Alpuche-Solís, A.G., RosalesMendoza, S., Moreno-Fierros, L., Bendik, E.M., Martínez-González, L., and Korban, S.S. (2009). Expression of a multi-epitope DPT fusion protein in transplastomic tobacco plants retains both antigenicity and immunogenicity of all three components of the functional oligomer. Planta 229, 1293-1302.

Sourrouille, C., Marshall, B., Liénard, D., and Faye, L. (2009). From Neanderthal to nanobiotech: from plant potions to pharming with plant factories. In Recombinant Proteins From Plants (Springer), pp. 1-23.

Spencer, D., Dickey, L.F., Gasdaska, J.R., Wang, X., Cox, K.M., and Peele, C.G. (2011). Expression of plasminogen and microplasminogen in duckweed (United States Google Patents).

Spök, A., Twyman, R.M., Fischer, R., Ma, J.K., and Sparrow, P.A. (2008). Evolution of a regulatory framework for pharmaceuticals derived from genetically modified plants. Trends Biotechnol. 26, 506-517.

Srinivasan, A., Yamini, K. N., Reddy, S. S., and Kumar, V. D. (2015). Tapetum specific expression of unedited nad3 gene from safflower and targeting the protein into mitochondria induces male sterility in transgenic tobacco plants. Plant Cell Tissue Organ Cult. 120, 387-398.

Stahl, R., Horvath, H., Van Fleet, J., Voetz, M., von Wettstein, D., and Wolf, N. (2002). T-DNA integration into the barley genome from single and double cassette vectors. Proc. Natl. Acad. Sci. U. S. A. 99, 2146-2151.

Stevens, L.H., Stoopen, G.M., Elbers, I.J., Molthoff, J.W., Bakker, H.A., Lommen, A., Bosch, D., and Jordi, W. (2000). Effect of climate conditions and plant developmental stage on the stability of antibodies expressed in transgenic tobacco. Plant Physiol. 124, 173-182.

Stoger, E., Sack, M., Fischer, R., and Christou, P. (2002a). Plantibodies: applications, advantages and bottlenecks. Curr. Opin. Biotechnol. 13, 161-166.

Stoger, E., Sack, M., Perrin, Y., Vaquero, C., Torres, E., Twyman, R.M., Christou, P., and Fischer, R. (2002b). Practical considerations for pharmaceutical antibody production in different crop systems. Mol. Breed. 9, 149-158.

Stöger, E., Vaquero, C., Torres, E., Sack, M., Nicholson, L., Drossard, J., Williams, S., Keen, D., Perrin, Y., and Christou, P. (2000). Cereal crops as viable production and storage systems for pharmaceutical scFv antibodies. Plant Mol. Biol. 42, 583-590.

Stomp, A.-M. (2005). The duckweeds: a valuable plant for biomanufacturing. Biotechnol. Annu. Rev. 11, 69-99.

Streatfield, S.J. (2007). Approaches to achieve high-level heterologous protein production in plants. Plant Biotechnol. J. 5, 2-15.

Streatfield, S.J., and Howard, J.A. (2003). Plant-based vaccines. Int. J. Parasitol. 33, 479-493.

Sun, N., Liu, M., Zhang, W., Yang, W., Bei, X., Ma, H., and Qi, X. (2015). Bean metal-responsive element-binding transcription factor confers cadmium resistance in tobacco. Plant Physiol. 167, 1136-1148.

Svanes, C., Sunyer, J., Plana, E., Dharmage, S., Heinrich, J., Jarvis, D., de Marco, R., Norbäck, D., Raherison, C., and Villani, S. (2010). Early life origins of chronic obstructive pulmonary disease. Thorax 65, 14-20.

Tacket, C.O., and Mason, H.S. (1999). A review of oral vaccination with transgenic vegetables. Microbes Infect. 1, 777-783.

Tait, R.C. (1999). The Application of Molecular Biology. Curr. Issues Mol. Biol. 1, 1-12.

Takahashi, M., Nakanishi, H., Kawasaki, S., Nishizawa, N.K., and Mori, S. (2001). Enhanced tolerance of rice to low iron availability in alkaline soils using barley nicotianamine aminotransferase genes. Nat. Biotechnol. 19, 466-469.

Talei, D., Valdiani, A., Rafii, M.Y., Maziah, M. (2014) Proteomic analysis of the salt-responsive leaf and root proteins in the anticancer plant Andrographis paniculata Nees. Plos One. 9, e112907. doi:10.1371/journal.pone. 0112907

Tarte, V. N., Seok, H. Y., Woo, D. H., Le, D. H., Tran, H. T., Baik, J. W., and Moon, Y. H. (2015). Arabidopsis QcSNARE gene AtSFT12 is involved in salt and osmotic stress responses and $\mathrm{Na}+$ accumulation in vacuoles. Plant Cell Rep. doi: 10.1007/ s00299-015-1771-3

Thanavala, Y., Yang, Y., Lyons, P., Mason, H., and Arntzen, C. (1995). Immunogenicity of transgenic plant-derived hepatitis B surface antigen. Proc. Natl. Acad. Sci. U. S. A. 92, 3358-3361.

Thompson, J.P., and Debinski, W. (1999). Mutants of interleukin 13 with altered reactivity toward interleukin 13 receptors. J. Biol. Chem. 274, 29944-29950.

Thomson, A.W., and Lotze, M.T. (2003). The Cytokine Handbook, Two-Volume Set (Gulf Professional Publishing). 
Tilman, D., Cassman, K.G., Matson, P.A., Naylor, R., and Polasky, S. (2002). Agricultural sustainability and intensive production practices. Nature 418, 671-677.

Torrent, M., Llompart, B., Lasserre-Ramassamy, S., LlopTous, I., Bastida, M., Marzabal, P., Westerholm-Parvinen, A., Saloheimo, M., Heifetz, P.B., and Ludevid, M.D. (2009). Eukaryotic protein production in designed storage organelles. BMC Biol. 7, 5 .

Tregoning, J.S., Clare, S., Bowe, F., Edwards, L., Fairweather, N., Qazi, O., Nixon, P.J., Maliga, P., Dougan, G., and Hussell, T. (2005). Protection against tetanus toxin using a plant based vaccine. Eur. J. Immunol. 35, 1320-1326.

Tremblay, R., Wang, D., Jevnikar, A.M., and Ma, S. (2010). Tobacco, a highly efficient green bioreactor for production of therapeutic proteins. Biotechnol. Adv. 28, 214-221.

Turner, N.C., Wright, G.C., and Siddique, K. (2001). Adaptation of grain legumes (pulses) to water-limited environments. Adv. Agron. 71, 194-233.

Twyman, R.M., Stoger, E., Schillberg, S., Christou, P., and Fischer, R. (2003). Molecular farming in plants: host systems and expression technology. Trends Biotechnol. 21, 570-578.

Valdiani, A., Javanmard, A., Talei, D., Tan, S.G., Nikzad, S., Kadir, M.A., Abdullah, S.N.A. (2013) Microsatellite-based evidences of genetic bottlenecks in the cryptic species "Andrographis paniculata Nees": A potential anticancer agent. Mol. Biol. Rep. 40, 1775-1784.

Valdiani, A., Kadir, M.A., Tan, S.G., Talei, D., Abdullah, M.P., Nikzad, S. (2012) Nain-e Havandi "Andrographis paniculata" present yesterday, absent today: a plenary review on underutilized herb of Iran's pharmaceutical plants. Mol. Biol. Rep. 39, 5409-5424.

Valdiani, A., Talei, D., Tan, S.G., Kadir, M.A., Maziah, M., Rafii, M.Y., Sagineedu, S.R. (2014) A classical genetic solution to enhance the biosynthesis of anticancer phytochemicals in Andrographis paniculata Nees. Plos One. 9, e87034. doi:10.1371/journal.pone.0087034

Van Droogenbroeck, B., Cao, J., Stadlmann, J., Altmann, F., Colanesi, S., Hillmer, S., Robinson, D.G., Van Lerberge, E., Terryn, N., and Van Montagu, M. (2007). Aberrant localization and underglycosylation of highly accumulating single-chain Fv-Fc antibodies in transgenic Arabidopsis seeds. Proceedings of the National Academy of Sciences 104, 1430-1435.

Vézina, L.-P., Faye, L., Lerouge, P., D'Aoust, M.-A., Marquet-Blouin, E., Burel, C., Lavoie, P.-O., Bardor, M., and Gomord, V. (2009). Transient co-expression for fast and high-yield production of antibodies with human-like $\mathrm{N}$-glycans in plants. Plant Biotechnol. J. 7, 442-455.

Vunsh, R., Li, J., Hanania, U., Edelman, M., Flaishman, M., Perl, A., Wisniewski, J.-P., and Freyssinet, G. (2007). High expression of transgene protein in Spirodela. Plant Cell Rep. 26, 1511-1519.

Walmsley, A.M., and Arntzen, C.J. (2000). Plants for delivery of edible vaccines. Curr. Opin. Biotechnol. 11, 126-129.

Walsh, G., and Jefferis, R. (2006). Post-translational modifications in the context of therapeutic proteins. Nat. Biotechnol. 24, 1241-1252.
Walter, C., Broer, I., Hillemann, D., and Pühler, A. (1992). High frequency, heat treatment-induced inactivation of the phosphinothricin resistance gene in transgenic single cell suspension cultures of Medicago sativa. Mol. Gen. Genet. 235, 189-196.

Wang, K. (2006a). Methods in Molecular Biology, Vol 1, $2^{\text {nd }}$ edn (New Jersey, USA: Humana press Totowa).

Wang, K. (2006b). Methods in Molecular Biology, Vol 2, $2^{\text {nd }}$ edn (New Jersey, USA: Humana press Totowa).

Wang, L. C., Wu, J. R., Hsu, Y. J., \& Wu, S. J. (2015). Arabidopsis HIT4, a regulator involved in heat-triggered reorganization of chromatin and release of transcriptional gene silencing, relocates from chromocenters to the nucleolus in response to heat stress. New Phytologist 205, 544-554.

Wang, T, E., Sandberg, R., Luo, S., Khrebtukova, I., Zhang, L., Mayr, C., Kingsmore, S.F., Schroth, G.P., and Burge, C.B. (2008). Alternative isoform regulation in human tissue transcriptomes. Nature 456, 470-476.

Wang, Y., Xue, Y., and Li, J. (2005). Towards molecular breeding and improvement of rice in China. Trends Plant Sci. 10, 610-614.

Ward, J., Bonaparte, M., Sacks, J., Guterman, J., Fogli, M., Mavilio, D., and Barker, E. (2007). HIV modulates the expression of ligands important in triggering natural killer cell cytotoxic responses on infected primary T-cell blasts. Blood 110, 1207-1214.

Wilkinson, S., and Davies, W.J. (2002). ABA-based chemical signalling: the co-ordination of responses to stress in plants. Plant, Cell Environ. 25, 195-210.

Woo, H. J., Sohn, S. I., Shin, K. S., Kim, J. K., Kim, B. G., and Lim, M. H. (2014). Expression of tobacco tocopherol cyclase in rice regulates antioxidative defense and drought tolerance. Plant Cell Tissue Organ Cult. 119, 257-267.

Wu, J., Yu, L., Li, L., Hu, J., Zhou, J., and Zhou, X. (2007). Oral immunization with transgenic rice seeds expressing VP2 protein of infectious bursal disease virus induces protective immune responses in chickens. Plant Biotechnol. J. 5, 570-578.

Xiong, L., and You, J. (2014). Use of OsPP18 Gene in Controlling Rice Drought Resistance. US Patent 20,140,373,193.

Xu, J., Dolan, M. C., Medrano, G., Cramer, C. L., and Weathers, P. J. (2012). Green factory: plants as bioproduction platforms for recombinant proteins. Biotechnol. Adv. 30, 1171-1184.

Xue, G.P. (2003). The DNA binding activity of an AP2 transcriptional activator HvCBF2 involved in regulation of low temperature responsive genes in barley is modulated by temperature. Plant J. 33, 373-383.

Yang, G., Li, J., Liu, W., Yu, Z., Shi, Y., Lv, B., and Han, D. (2015). Molecular cloning and characterization of MxNAS2, a gene encoding nicotianamine synthase in Malus xiaojinensis, with functions in tolerance to iron stress and misshapen flower in transgenic tobacco. Sci. Hortic. 183, 77-86.

Yang, X., Wang, X., Ji, L., Yi, Z., Fu, C., Ran, J., and Zhou, G. (2015). Overexpression of a Miscanthus lutarioriparius NAC gene MINAC5 confers enhanced drought and cold 
tolerance in Arabidopsis. Plant Cell Reports. doi: 10.1007/s00299-015-1756-2

Yano, M., Hirai, T., Kato, K., Hiwasa-Tanase, K., Fukuda, N., and Ezura, H. (2010). Tomato is a suitable material for producing recombinant miraculin protein in genetically stable manner. Plant Sci. 178, 469-473.

Yokoo, T., Matsumoto, K. I., Ooba, T., Morimoto, K., and Taguchi, S. (2015). Enhanced poly (3-hydroxybutyrate) production in transgenic tobacco BY-2 cells using engineered acetoacetyl-CoA reductase. Biosci. Biotechnol. Biochem. doi: 10.1080/09168451.2014.1002448

Yokoya, N.S., Ávila, M., Piel, M.I., Villanueva, F., and Alcapan, A. (2014). Effects of plant growth regulators on growth and morphogenesis in tissue culture of Chondracanthus chamissoi (Gigartinales, Rhodophyta). J. Appl. Phycol. 26, 819-823.

Yoon, S.-M., Kim, S.Y., Li, K.F., Yoon, B.H., Choe, S., and Kuo, M.M.-C. (2011). Transgenic microalgae expressing Escherichia coli AppA phytase as feed additive to reduce phytate excretion in the manure of young broiler chicks. Appl. Microbiol. Biotechnol. 91, 553-563.

Yoshida, T., Fujita, Y., Maruyama, K., Mogami, J., Todaka, D., Shinozaki, K., and Yoshida T, Fujita Y, Maruyama K, Mogami J, Todaka D, Shinozaki K, Yamaguchi-Shinozaki K. (2015). Four Arabidopsis AREB/ABF transcription factors function predominantly in gene expression downstream of SnRK2 kinases in abscisic acid signaling in response to osmotic stress. Plant Cell Environ. 38, 35-49.

Youm, J.W., Jeon, J.H., Kim, H., Kim, Y.H., Ko, K., Joung, H., and Kim, H. (2008). Transgenic tomatoes expressing human beta-amyloid for use as a vaccine against Alzheimer's disease. Biotechnol. Lett. 30, 1839-1845.

Young, A., Lyons, J., Miller, A.L., Phan, V.T., Alarcón, I.R., and McCormick, F. (2009). Ras signaling and therapies. Adv. Cancer Res. 102, 1-17.

Zaslavskaia, L.A., Lippmeier, J.C., Kroth, P.G., Grossman, A.R., and Apt, K.E. (2000). Transformation of the diatom Phaeodactylum tricornutum (Bacillariophyceae) with a variety of selectable marker and reporter genes. J. Phycol. 36, 379-386.

Zhang, D., Nandi, S., Bryan, P., Pettit, S., Nguyen, D., Santos, M.A., and Huang, N. (2010). Expression, purification, and characterization of recombinant human transferrin from rice (Oryza sativa L.). Protein Expr. Purif. 74, 69-79.
Zhang, G.G., Rodrigues, L., Rovinski, B., and White, K.A. (2002). Production of HIV-1 p24 protein in transgenic tobacco plants. Mol. Biotechnol. 20, 131-136.

Zhang, H., Liu, J., Hou, J., Yao, Y., Lin, Y., Ou, Y., Song, Botao., and Xie, C. (2014). The potato amylase inhibitor gene $S b A$ l regulates cold-induced sweetening in potato tubers by modulating amylase activity. Plant Biotechnol. J. 12, 984-993.

Zhang, Q., Walawage, S. L., Tricoli, D. M., Dandekar, A. M., and Leslie, C. A. (2015). A red fluorescent protein (DsRED) from Discosoma $\mathrm{sp}$. as a reporter for gene expression in walnut somatic embryos. Plant Cell Rep. doi: $10.1007 / \mathrm{s} 00299-015-1749-1$

Zhang, Z., Huang, R. (2010). Enhanced tolerance to freezing in tobacco and tomato overexpressing transcription factor TERF2/LeERF2 is modulated by ethylene biosynthesis. Plant Mol. Biol. 73, 241-9.

Zhao, Y., Ma, Q., Jin, X., Peng, X., Liu, J., Deng, L., Yan, H., Sheng, L., Jiang, H., and Cheng, B. (2014). A novel maize homeodomain-leucine zipper (HD-Zip) I gene, $Z m h d z 10$, positively regulates drought and salt tolerance in both rice and arabidopsis. Plant Cell Physiol. 55, 1142-1156.

Zhong, L., Chen, D., Min, D., Li, W., Xu, Z., Zhou, Y., and Ma, Y. (2015). AtTGA4, a bZIP transcription factor, confers drought resistance by enhancing nitrate transport and assimilation in Arabidopsis thaliana. Biochem. Biophys. Res. Commun. 457, 433-439.

Zhu, S., Li, Y., Vossen, J. H., Visser, R. G., and Jacobsen, E. (2012). Functional stacking of three resistance genes against Phytophthora infestans in potato.Transgenic Res. 21, 89-99.

Zhu, X.-G., Long, S.P., and Ort, D.R. (2008). What is the maximum efficiency with which photosynthesis can convert solar energy into biomass? Curr. Opin. Biotechnol. 19, 153-159.

Zhu, Z., Hughes, K.W., Huang, L., Sun, B., Liu, C., and Li, Y. (1994). Expression of human $\alpha$-interferon cDNA in transgenic rice plants. Plant Cell Tiss. Org. Cult. 36, 197-204.

Ziemienowicz, A. (2013). Agrobacterium-mediated plant transformation: Factors, applications and recent advances. Biocatal. Agric. Biotechnol. 3, 95-102.

Ziemienowicz, A., Shim, Y.-S., Matsuoka, A., Eudes, F., and Kovalchuk, I. (2012). A novel method of transgene delivery into triticale plants using the Agrobacterium transferred DNA-derived nano-complex. Plant Physiol. 158, 1503-1513. 


\section{Microbiology / Molecular Biology}

Caister Academic Press is a leading academic publisher of advanced texts in microbiology, molecular biology and medical research. Full details of all our publications at caister.com

- Cyanobacteria: Omics and Manipulation Edited by: DA Los (2017) www.caister.com/cyano3

- Brain-eating Amoebae: Biology and Pathogenesis of Naegleria fowleri

Author: R Siddiqui, IKM Ali, JR Cope, et al. (2016)

"explains the current knowledge and research" (ProtoView) www.caister.com/naegleria

- Foot and Mouth Disease Virus: Current Research and Emerging Trends

Edited by: F Sobrino, E Domingo (2017)

www.caister.com/fmdv

- Staphylococcus: Genetics and Physiology

Edited by: GA Somerville (2016)

www.caister.com/staph2

- Chloroplasts: Current Research and Future Trends Edited by: H Kirchhoff (2016)

www.caister.com/chloroplasts

- Microbial Biodegradation: From Omics to Function and Application

Edited by: J Długoński (2016)

www.caister.com/biodegradation

- Influenza: Current Research

Edited by: Q Wang, YJ Tao (2016)

www.caister.com/flu3

- MALDI-TOF Mass Spectrometry in Microbiology Edited by: M Kostrzewa, S Schubert (2016)

www.caister.com/malditof

- Aspergillus and Penicillium in the Post-genomic Era Edited by: RP Vries, IB Gelber, MR Andersen (2016)

"new and well-presented book" (IMA Fungus)

www.caister.com/aspergillus2

- The Bacteriocins: Current Knowledge and Future

Prospects

Edited by: RL Dorit, SM Roy, MA Riley (2016)

www.caister.com/bacteriocins

- Omics in Plant Disease Resistance

Edited by: V Bhadauria (2016)

"essential reading ... highly recommended" (Biotechnol. Agron.

Soc. Environ.)

www.caister.com/opdr

- Acidophiles: Life in Extremely Acidic Environments

Edited by: R Quatrini, DB Johnson (2016)

"Contributors from a wide range of biological and environmental sciences" (ProtoView)

www.caister.com/acidophiles
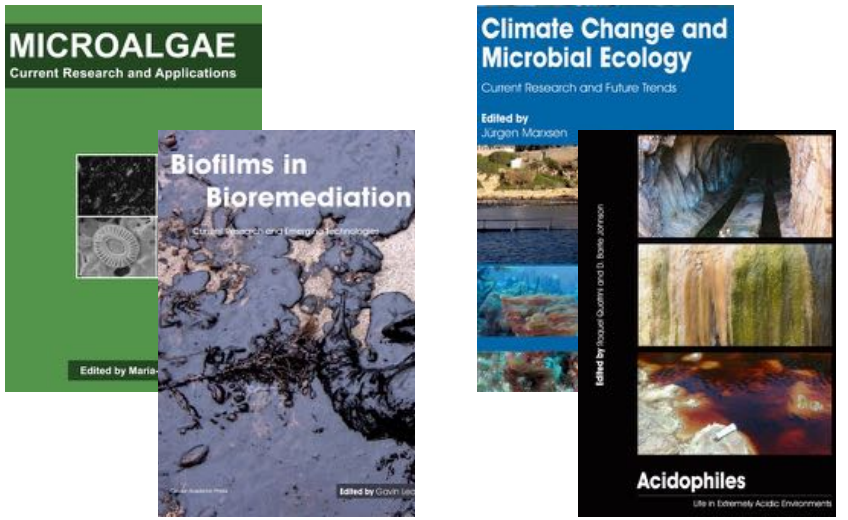
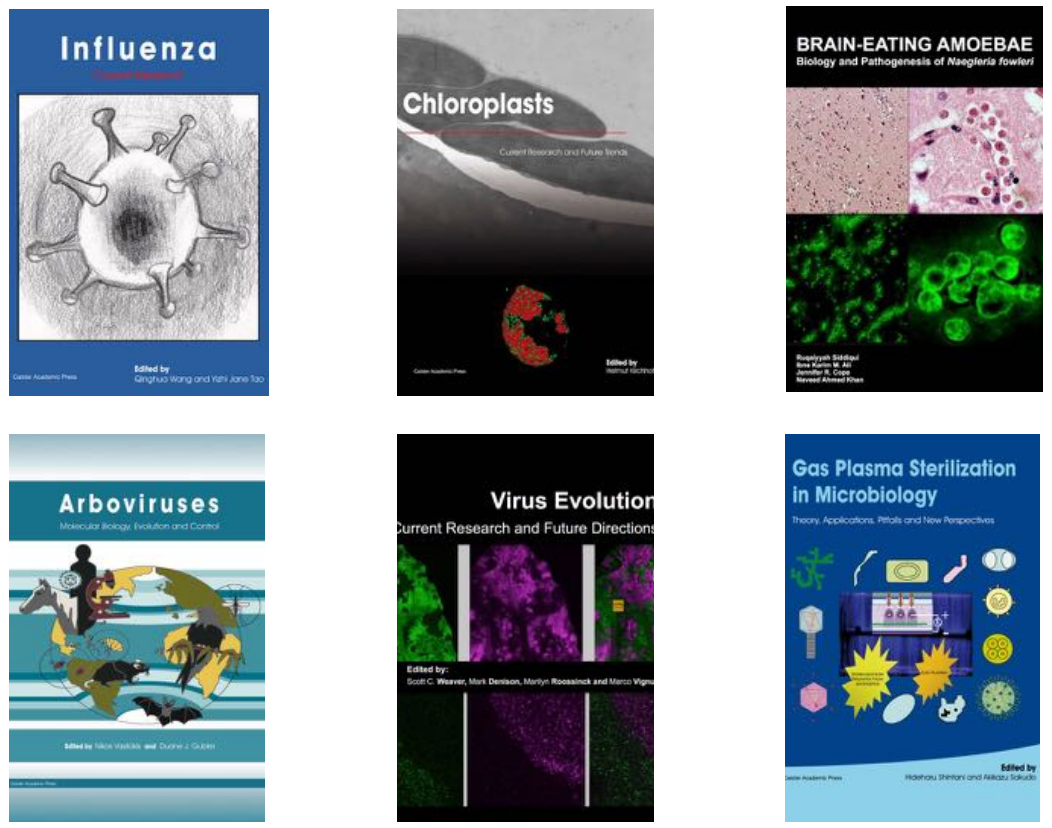

- Climate Change and Microbial Ecology: Current Research and Future Trends

Edited by: J Marxsen (2016)

"impressive" (ASM: Small Things Considered); "written at a high scientific level" (BioSpektrum)

www.caister.com/climate

- Biofilms in Bioremediation: Current Research and Emerging Technologies

Edited by: G Lear (2016)

"describes explicitly the role of biofilms in bioremediation" (Biospektrum); indispensable ... recommended (Biotechnol. Agron. Soc. Environ.) www.caister.com/biorem

- Microalgae: Current Research and Applications

Edited by: MN Tsaloglou (2016)

www.caister.com/microalgae

- Gas Plasma Sterilization in Microbiology: Theory, Applications, Pitfalls and New Perspectives

Edited by: H Shintani, A Sakudo (2016)

"a nice state of the art compilation" (Doodys)

www.caister.com/gasplasma

- Virus Evolution: Current Research and Future Directions Edited by: SC Weaver, M Denison, M Roossinck, et al. (2016) "highly informative ... a pleasure to read" (Microbiol. Today) www.caister.com/virusevol

- Arboviruses: Molecular Biology, Evolution and Control Edited by: N Vasilakis, DJ Gubler (2016)

"a thorough and compelling review ... an outstanding book ... highly recommended" (Am. J. Trop. Med. Hyg.) www.caister.com/arbo

- Shigella: Molecular and Cellular Biology

Edited by: WD Picking, WL Picking (2016)

www.caister.com/shigella

- Aquatic Biofilms: Ecology, Water Quality and Wastewater Treatment

Edited by: AM Romaní, H Guasch, MD Balaguer (2016)

"essential reference book" (Biotechnol. Agron. Soc. Environ.)

www.caister.com/aquaticbiofilms

- Alphaviruses: Current Biology

Edited by: S Mahalingam, L Herrero, B Herring (2016)

"up-to-date review of the field" (Aus. Vet. J.)

www.caister.com/alpha 